Acta Protozool. (2018) 57: 123-143 www.ejournals.eu/Acta-Protozoologica doi:10.4467/16890027AP.18.011.8985 PROTOZOOLOGICA

\title{
New discoveries of the genus Thuricola Kent, 1881 (Ciliophora, Peritrichia, Vaginicolidae), with descriptions of three poorly known species from China
}

\author{
Borong LU', Daode JI $^{2}$, Yalan SHENG ${ }^{1}$, Weibo SONG ${ }^{1}$, Xiaozhong HU ${ }^{1,5}$, Xiangrui CHEN², \\ Khaled A. S. AL-RASHEID ${ }^{4}$,
}

\begin{abstract}
${ }^{1}$ Institute of Evolution and Marine Biodiversity \& Key Laboratory of Mariculture, Ministry of Education, Ocean University of China, Qingdao, China; ${ }^{2}$ School of Ocean, Yantai University, Yantai, China; ${ }^{3}$ School of Marine Sciences, Ningbo University, Ningbo, China; ${ }^{4}$ Zoology Department, King Saud University, Riyadh, Saudi Arabia; ${ }^{5}$ Laboratory for Marine Biology and Biotechnology, Qingdao National Laboratory for Marine Science and Technology, Qingdao, China
\end{abstract}

\begin{abstract}
Members of the genus Thuricola are a highly specialized group of peritrichous ciliates possessing a protective barrel-shaped lorica. The genus presents many difficulties in terms of species separation and definition, and in this context the present study investigates three species by protargol staining and analyses of SSU rDNA sequences. Based on their morphologic characteristics and biotope, they were identified as three poorly known forms in Thuricola, namely T. obconica Kahl, 1933, T. kellicottiana (Stokes, 1887) Kahl 1935 and T. folliculata Kent, 1881, respectively. T. obconica is characterized by possessing curved lorica and a single valve in vivo. T. kellicottiana is distinguished by two valves with a spine on the main valve, and a generally long internal stalk upon which the zooids sit. T. folliculata also has two valves but lacks a spine. The ciliature of the three species are basically similar. The main features are characterized as follows: infundibular polykineties 1-3 (P1-3) are relatively long and composed of three rows each; P1 bends twice and comprises three equally long rows; P2 ends near the second bend of P1 with all rows exhibiting a staggered arrangement; P3 converges with P1 at adstomal end, its row 1 at least twice as long as the other two rows; epistomial membranes 1 and 2 are present. Silverline system in Vorticella-pattern. Phylogenetic analyses indicate that the three ciliates in this study cluster together within one of the two major sub-clades within the Vaginicolidae.
\end{abstract}

Keywords: Ciliate; Loricate sessilids; Molecular phylogeny; Morphology; Silverline

\section{INTRODUCTION}

Sessile peritrichs are a large assemblage of ciliates that have a wide distribution in aquatic and terrestrial habitats (Kahl 1935, Foissner et al. 1992, Ji et al. 2015,

Address for correspondence: Xiaozhong $\mathrm{Hu}$, Institute of Evolution and Marine Biodiversity \& Key Laboratory of Mariculture, Ministry of Education, Ocean University of China, 5 Yushan Road, Qingdao 266003, China; Tel./FAX: +86 5328203 1610; E-mail: xiaozhonghu@ouc.edu.cn
Sun et al. 2017, Shen et al. 2017). Up to now, more than 800 species have been reported (Lynn 2008, Foissner $e t$ al. 2010), and continuously emerging new taxa suggest that there is a large undiscovered diversity of this group (Peng et al. 2007, Foissner et al. 2010, Ji et al. 2015, Zhuang et al. 2016, Liu et al. 2017, Shen et al. 2017, Sun et al. 2017).

Unfortunately, the loricate sessilids have been largely neglected in modern taxonomic studies compared to non-loricate forms owing to their relatively low abundance in nature. As the biggest family among the 
loricate peritrichs, including nearly 200 nominal species, the Vaginicolidae in particular is insufficiently known and is thus in need of thorough research, especially in respect to the ciliature and molecular information.

Thuricola is a relatively small genus of the Vaginicolidae, and was established by Kent (1881). It is distinguished from other vaginicolids by the closure apparatus of the lorica, which is the crucial feature of the genus and is used to enclose the organism (Kahl 1935; Trueba 1978, 1980; Warren 1982, 1991). A series of studies have been carried out on this genus since the late nineteenth century, before Trueba (1980) revised the genus to include 11 species (Wright 1858, Kent 1881; Stokes 1882, 1887; Daday 1910, Kahl 1933, Sommer 1951, Hammann 1952, Biernacka 1963, Bock 1963, Küsters 1974). Thereafter, six new species found in China were added to the genus (Gong 1989a, b; Xu 1990; Sun et al. 2009, 2012; Shen and Gu 2016).

Similar to other vaginicolids, ciliature data on Thuricola are very scarce (Kahl 1935; Trueba 1978, 1980; Xu 1990, Warren 1991, Zhuang et al. 2016), and many descriptions are either outdated or very ambiguous (Fromentel 1874; Penard 1914, 1922; Dons 1922, 1948; Kahl 1933, Bock 1952, Stiller 1971). In addition, although molecular data are playing an increasingly important role in the taxonomy and systematics of ciliates (Li et al. 2013, Chen et al. 2016; Gao et al. 2016a, 2017; Huang et al. 2016, Sun et al. 2016, Gentekaki et al. 2017, Wang et al. 2017, Zhuang et al. 2018), little such information is so far available for Thuricola.

The current work is a new contribution and a part of the ongoing faunistic study of ciliates in China $(\mathrm{Qu}$ et al. 2015; Liu et al. 2016; Lu et al. 2017; Pan et al. 2017). Three little-known species of Thuricola are described based on careful observations of specimens in vivo and after silver staining. Their living morphology and ciliature are presented, together with a phylogenetic analysis based on their SSU rDNA sequences.

\section{MATERIALS AND METHODS}

Materials and morphological methods: Thuricola obconica was isolated from the surface of green algae (Enteromopha sp.) collected on February $20^{\text {th }} 2017$ from an aquaculture pond with brackish water (salinity $11 \%$ ) on Meishan Island (N29 $36^{\prime}$; E121 ${ }^{\circ} 48^{\prime}$ ), Ningbo, China. The water temperature was $14.5^{\circ} \mathrm{C}$.

Thuricola kellicottiana was also isolated from the surface of Enteromopha algae, which was collected on March $10^{\text {th }} 2017$ near a floodgate on Meishan Island (N29 $36^{\prime}$; E121 ${ }^{\circ} 48^{\prime}$ ), Ningbo, China. The water temperature was $13.5^{\circ} \mathrm{C}$ and the salinity $6.5 \%$.
Population-I of Thuricola folliculata was obtained from samples of the aquatic plant Ceratophyllum demersum, collected on March $16^{\text {th }} 2017$ from the wetland of Hangzhou Bay (N30 $\left.22^{\prime} ; \mathrm{E} 121^{\circ} 12^{\prime}\right)$, Ningbo, China. The water temperature was $9.5^{\circ} \mathrm{C}$ and the salinity was $2 \%$. Population-II was isolated on April $24^{\text {th }} 2017$ from a fresh water lake $\left(\mathrm{N} 36^{\circ} 04^{\prime}\right.$; E120 $\left.21^{\prime}\right)$ in Qingdao, China. The water temperature was $14^{\circ} \mathrm{C}$.

The living morphology was investigated under a compound microscope equipped with a high-power oil immersion objective as well as differential interference contrast optics. The ciliature was revealed using the protargol staining method (Wilbert 1975). The protargol powder was manually synthesized, following the method prescribed by Pan et al. (2013). Counts and measurements were performed at 400-1,000 $\times$ magnification. Drawings were made with the help of a camera lucida. Terminology is mainly according to Trueba (1980) and Lynn (2008) except for the following:

Junctional membrane (JM): The lorica closure apparatus is a distinctive feature of Thuricola. It is composed of valve(s) that can close the lorica through traction of a thin membrane. This membrane is funnel-shaped, surrounds zooid and stalk. View from narrow side of lorica, its anterior portion is normally invisible because it attaches to inner wall tightly. Due to the lack of study of this genus, there is no accepted term for this thin membrane. Moreover, the term 'membrane' in ciliates often refers to orderly arranged cilia. Considering that it connects the valve to the bottom of the lorica, we therefore introduce this term here.

Lorica base (LB): A term referring to the bottom of lorica that attaches to the substrate.

DNA extraction, PCR amplification and sequencing: Genomic DNA was extracted from cells using the DNeasy Blood \& Tissue Kit (Qiagen, Hilden, Germany) following the manufacturer's instructions. The small subunit (SSU) rDNA sequence was amplified by PCR using the primers: $82 \mathrm{~F}$ (5' -GAAACT GCG AAT GGC TC-3') (Jerome et al. 1996) and 18s-R (5'-TGA TCC TTC TGC AGG TTC ACC TAC-3') (Medlin et al. 1988). Q5 ${ }^{\circledR}$ Hot Start High-Fidelity DNA Polymerase (New England BioLabs, USA) was used to minimize the possibility of PCR amplification errors. Sequencing was performed bidirectionally by the Tsingke Biological Technology Company (Beijing, China).

Phylogenetic analyses: In addition to the three SSU rDNA sequences obtained in this study, 42 sequences of representative peritrichs downloaded from the GenBank database were included in the present phylogenetic analyses. Three hymenostomatian species, Tetrahymena thermophila, Tetrahymena corlissi and Glaucoma chattoni were used as the outgroup taxa. All sequences were first aligned using the GUIDANCE2 algorithm (Landan and Graur 2008; Sela et al. 2015). The resulting alignment was then manually refined by trimming both ends using the program BioEdit 7.0 (Hall 1999), resulting in a matrix of 1763 characters. Maximum likelihood (ML) analysis was computed at the CIPRES website (http://www.phylo. org), using the GTR + gamma model performed by RAxML-HPC2 v.8.2.10 on XSEDE (Stamatakis 2014). The highest-scoring ML tree was assessed by 1,000 bootstrap replicates. Bayesian inference (BI) analysis was performed with MrBayes v.3.2.6 on XSEDE (Ronquist et al. 2012) using the GTR $+\mathrm{I}+\mathrm{G}$ model selected by MrModeltest 2.2 (Nylander 2004) under the Akaike Information Criterion. Markov chain Monte Carlo simulations were run for $6,000,000$ genera- 
tions with a sample frequency of 100 generations. The first $10 \%$ of trees were discarded as burn-in. All the remaining trees were used to calculate the posterior probability using a $50 \%$ majority rule consensus. Tree topologies were visualized using MEGA 7.0 (Kumar et al. 2016). Systematic classification is according to Sun et al. (2012) and Gao et al. (2016b).

\section{RESULTS}

\section{Subclass Peritrichia Stein, 1859}

\section{Order Sessilida Kahl, 1933}

\section{Family Vaginicolidae Fromentel, 1874}

\section{Genus Thuricola Kent, 1881}

Hitherto Thuricola has never been defined based on the ciliature information and descriptions of most thuricolas are incomplete. Here, three species of Thuricola were investigated carefully in vivo and their ciliature were revealed for the first time. Thus we provide an improved diagnosis as follows.

Emended diagnosis: One or two zooids within a closeable lorica. Zooid(s) attached to base of lorica directly or via a single stalk. Lorica attached to substrate directly. Valve and junctional membrane present. Infundibular polykinety 3 consisting of three rows of kinetosomes, row 1 of which is distinctly longer than the other two. Silverline system in Vorticella-pattern.

\section{Thuricola obconica Kahl, 1933 (Figs 2A-R, 3A-S, Table 1)}

1933 Thuricola obconica n. sp.-Kahl, Tierwelt Nord Ostsee., p. 135, Fig. 24: 7.

1935 Thuricola obconica Kahl, 1933-Kahl, Tierwelt Dtl., p. 786, Fig. 145: 7-8.

1952 Thuricola obconica Kahl, 1933-Bock, Kieler Meeresforsch., 8: p. 227, Fig. 2a, b.

1952 Thuricola kamptostoma n. sp.-Bock, Kieler Meeresforsch., 8: p. 227-228, Fig. 3.

1980 Thuricola obconica Kahl, 1933-Trueba, Beaufortia, 30: p. 134, Fig. 5g.

Although T. obconica had been described several times, morphological data on the species remain somewhat deficient. Furthermore, the inconsistencies in the descriptions provided in the literature suggest that the previous studies may contain some misidentifications. A detailed redescription based on modern criteria is therefore imperative.
Emended diagnosis: Lorica colourless and ca. 120-210 $\mu \mathrm{m}$ long, cross-section sub-circular, nearly symmetrical on wider side and asymmetrical on narrower side, curved before valve base, posterior portion tapering to a base with two annular bulges, base expanded. Valve in upper third of lorica. One or two zooids, $195-310 \times 15-32 \mu \mathrm{m}$ in vivo. Stalk about $10 \mu \mathrm{m}$ long. Peristomial lip single-layered and strongly everted. Contractile vacuole dorsally located. Row 1 of infundibular polykinety 3 about twice as long as the other two. About 105-120 transverse silverlines from peristome to trochal band, 95-110 from trochal band to scopula.

Voucher slides: Six voucher slides with protargol stained specimens (registration number LU2017022001-01-06) have been deposited in the Laboratory of Protozoology, Ocean University of China.

Description: Cell size about 195-310 × 15-25 $\mu \mathrm{m}$ $(\mathrm{n}=9)$ in vivo. Generally, one or two zooids within a lorica. When two zooids co-exist, they are abreast of each other but anisometric. Solitary zooid relatively smaller. When extended, zooid is slender and trumpet-shaped, expanded gradually anteriad, widest at oral opening (Figs 2A-D, 3A-E). Zooid highly flexible and contractile. When stimulated, zooid contracts into lorica and becomes ellipsoid or broadly conical in outline (Fig. $3 \mathrm{~F}-\mathrm{H})$. Peristomial lip thin and single-layered, about $38-48 \mu \mathrm{m}$ in diameter when fully expanded. Peristomial disc strongly elevated (Figs 2A, B, 3A-E, I). Pellicle covered with shallow, narrowly spaced traverse striations (Figs 2J, 3N). Striations hardly recognizable at low magnifications, but clearly visible above $400 \times$ magnification. Trochal band, a conspicuously bulged ring-like structure, located near mid-body (Figs 2J, $3 \mathrm{~N})$. About 105-120 striations from peristome to trochal band and 95-110 striations from trochal band to scopula (counted from live materials; $n=4$ ).

Cytoplasm colourless and full of granules usually less than $2 \mu \mathrm{m}$ in diameter. Single contractile vacuole located at the same level as peristomial lip and on the dorsal wall of infundibulum (Figs 2A, B, 3I). Food vacuoles about $5-10 \mu \mathrm{m}$ across, usually positioned in the middle portion of body (Figs 2A, B, 3A-H). Sometimes, several large irregular-shaped refractive granules scattered in cytoplasm.

Macronucleus rather hyaline and thus difficult to recognize in vivo, vermiform in shape, longitudinally oriented, nearly passing through the whole body with a transverse curvature at oral end, attenuating gradually from top to bottom (Figs 2C, 3O-Q). Due to 
Table 1. Morphometric data of Thuricola obconica (first line), Thuricola kellicottiana (second line) and Thuricola folliculata (population I, third line; population II, last line).

\begin{tabular}{|c|c|c|c|c|c|c|}
\hline Characters $^{\mathrm{a}}$ & Min & Max & Mean & SD & $\mathrm{CV}$ & $\mathrm{n}$ \\
\hline \multirow[t]{4}{*}{ Body length } & 195 & 310 & 243.0 & 38.1 & 15.7 & 9 \\
\hline & 230 & 377 & 287.9 & 45.5 & 15.8 & 9 \\
\hline & 165 & 288 & 237.1 & 42.2 & 17.8 & 7 \\
\hline & 180 & 313 & 221.6 & 43.7 & 19.7 & 10 \\
\hline \multirow[t]{4}{*}{ Body width } & 18 & 23 & 20.6 & 1.6 & 7.8 & 9 \\
\hline & 21 & 27 & 23.9 & 1.7 & 7.1 & 9 \\
\hline & 18 & 23 & 20.1 & 1.9 & 9.5 & 7 \\
\hline & 16 & 23 & 19.3 & 2.1 & 10.9 & 10 \\
\hline \multirow[t]{4}{*}{ Peristomial lip width } & 38 & 48 & 43.2 & 3.7 & 8.6 & 9 \\
\hline & 40 & 48 & 42.7 & 2.5 & 5.9 & 9 \\
\hline & 36 & 42 & 39.0 & 2.0 & 5.1 & 7 \\
\hline & 37 & 50 & 40.2 & 4.0 & 10.0 & 10 \\
\hline \multirow[t]{4}{*}{ Lorica length } & 155 & 210 & 178.6 & 16.2 & 9.1 & 10 \\
\hline & 190 & 225 & 201.5 & 12.6 & 6.3 & 6 \\
\hline & 155 & 186 & 167.4 & 10.7 & 6.4 & 7 \\
\hline & 127 & 168 & 139.7 & 14.6 & 10.5 & 6 \\
\hline \multirow[t]{4}{*}{ Lorica width from narrow side } & 39 & 50 & 46.5 & 3.4 & 7.3 & 10 \\
\hline & 44 & 50 & 46.8 & 2.0 & 4.3 & 6 \\
\hline & 45 & 51 & 48.9 & 2.7 & 5.5 & 7 \\
\hline & 39 & 46 & 42.2 & 2.8 & 6.6 & 5 \\
\hline \multirow[t]{4}{*}{ Lorica width from wide side } & 47 & 47 & 47.0 & 0 & 0 & 1 \\
\hline & 51 & 54 & 52.5 & 2.1 & 4.0 & 2 \\
\hline & 50 & 50 & 50.0 & 0 & 0 & 1 \\
\hline & 48 & 52 & 50.0 & 2.8 & 5.6 & 2 \\
\hline \multirow[t]{4}{*}{ Aperture width from narrow side } & 31 & 43 & 37.7 & 4.4 & 11.7 & 7 \\
\hline & 32 & 40 & 35.5 & 2.9 & 8.2 & 6 \\
\hline & 33 & 39 & 36.4 & 2.0 & 5.5 & 7 \\
\hline & 32 & 39 & 35.5 & 2.6 & 7.3 & 6 \\
\hline \multirow[t]{4}{*}{ Aperture width from wide side } & 47 & 47 & 47.0 & 0 & 0 & 1 \\
\hline & 49 & 51 & 50.0 & 1.4 & 2.8 & 2 \\
\hline & 50 & 50 & 50.0 & 0 & 0 & 1 \\
\hline & 48 & 52 & 50.0 & 2.8 & 5.6 & 2 \\
\hline \multirow[t]{4}{*}{ Stalk length } & 6 & 14 & 10.6 & 2.6 & 24.5 & 9 \\
\hline & 4 & 18 & 14.0 & 5.1 & 36.5 & 6 \\
\hline & 5 & 13 & 7.3 & 2.8 & 38.4 & 7 \\
\hline & 3 & 6 & 4.6 & 1.1 & 23.9 & 5 \\
\hline \multirow[t]{4}{*}{ Number of valves } & 1 & 1 & 1.0 & 0 & 0 & 10 \\
\hline & 2 & 2 & 2.0 & 0 & 0 & 6 \\
\hline & 2 & 2 & 2.0 & 0 & 0 & 7 \\
\hline & 2 & 2 & 2.0 & 0 & 0 & 6 \\
\hline \multirow[t]{4}{*}{ Number of striations from peristome to $\mathrm{TB}^{\mathrm{b}}$} & 104 & 120 & 111.8 & 7.1 & 6.4 & 4 \\
\hline & 95 & 103 & 99.0 & 5.7 & 5.8 & 2 \\
\hline & 110 & 115 & 112.5 & 3.5 & 3.1 & 2 \\
\hline & 97 & 111 & 107.3 & 6.8 & 6.3 & 4 \\
\hline \multirow[t]{4}{*}{ Number of striations from TB to scopula ${ }^{\mathrm{b}}$} & 96 & 111 & 101.8 & 6.5 & 6.4 & 4 \\
\hline & 100 & 108 & 103.6 & 3.2 & 3.1 & 5 \\
\hline & 95 & 108 & 103.0 & 2.7 & 2.6 & 4 \\
\hline & 87 & 106 & 93.8 & 8.7 & 9.3 & 4 \\
\hline
\end{tabular}

${ }^{a}$ Data based on living specimens. Measurements in $\mu \mathrm{m}$.

${ }^{\mathrm{b}}$ Rough values.

$\mathrm{CV}$, coefficient of variation in \%; Max, maximum; Mean, arithmetic mean; Min, minimum; $n$, number of individuals examined; TB, trochal band. 


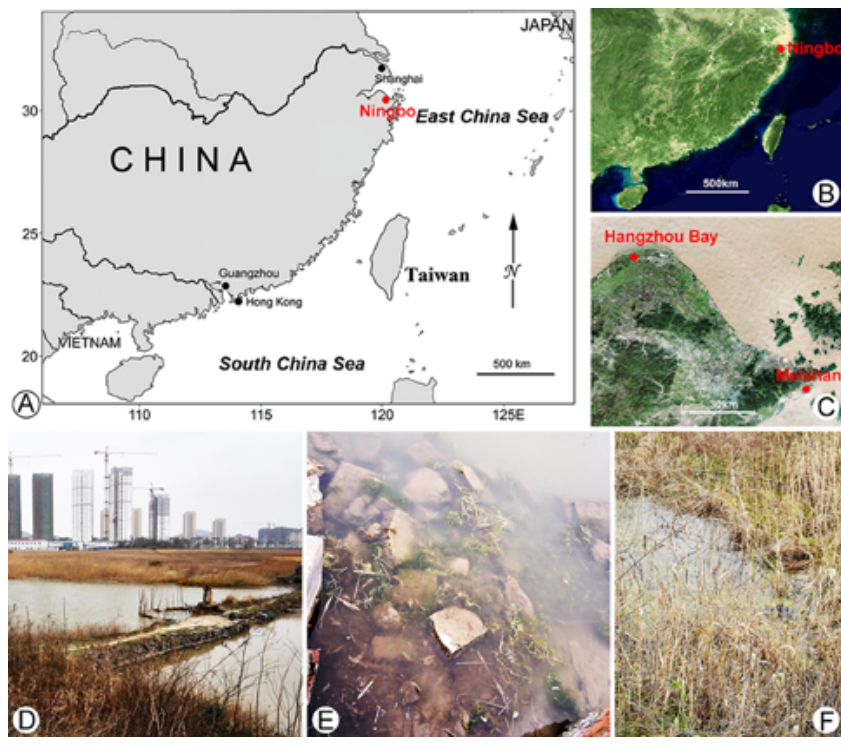

Fig. 1. (A, B) Map of East China Sea and South China Sea, red dot indicates the location of Ningbo. (C) Satellite map of North-east Ningbo, red dots indicate the two sampling areas (Wetland of Hangzhou Bay and Meishan Island). (D) A brackish aquaculture pond in Meishan Island. (E) Close up of a watercourse in Meishan Island. (F) Wetland of Hangzhou Bay.

significant shrinkage in the fixation process, macronucleus in protargol stained specimens highly twisted (Figs 2L, 3O-Q).

Zooid attached to lorica via an inner stalk, around $10 \mu \mathrm{m}$ long (Figs 2A-D, 3A-H). Stalk has longitudinal striations only visible at high magnifications. Both ends of stalk expanded (Figs 2I, 3K).

Lorica of Thuricola obconica transparent and colourless, about 155-210 $\mu \mathrm{m}$ long, conical in aboral third and with a laterally bent anterior portion. In lateral view from the narrow side, lorica about 40-50 $\mu \mathrm{m}$ (average $46.5 \mu \mathrm{m}, \mathrm{n}=10$ ) wide, widest about two-thirds of its length from aperture to base (Figs $2 \mathrm{~A}-\mathrm{C}, \mathrm{F}-\mathrm{H}, 3 \mathrm{~A}-\mathrm{H}$ ). Lorica usually bent differently at anterior third (Figs $2 \mathrm{~A}-\mathrm{H}, 3 \mathrm{~A}, \mathrm{D}, \mathrm{E}, \mathrm{F}, \mathrm{H})$. In lateral view from the wide side, lorica slightly wider $(47 \mu \mathrm{m}, \mathrm{n}=1)$, and almost rectangular in outline at upper two thirds (Figs 2D, 3C). At posterior third, lorica narrowed with two inconspicuous annular bulges (Figs 2A-H, 3A-H, K, L). Bottom expanded (Figs 2I, 3K, arrow). One valve inserted at anterior third (Figs 2A-H, 3A-H, M). Its base curved and thus conducive to closing and opening (Figs 2A-C, F-H, 3A, B, D-H, M). Valve connected to a junctional membrane (JM). JM thin and hyaline, making it hard to confirm fine three-dimensional structure under light microscope. Viewed from the narrower side of lorica, JM presents two short "V" shaped lines above inner stalk and two short longitudinal lines around stalk (Figs 2A$\mathrm{C}, \mathrm{F}-\mathrm{H}, 3 \mathrm{~K}$, arrow), whereas it shows two long lines that nearly symmetrical with smooth curves above inner stalk and two short longitudinal lines around stalk between valve and lorica floor when lorica rotated by $90^{\circ}$ (Figs 2E, 3C, L, arrowheads).

Oral cilia about $18 \mu \mathrm{m}$ long, positioned around peristomial disc and lip. Oral apparatus composed of haplokinety and polykinety; both circling about 1.5 turns around peristomial disc before entering infundibulum where they make a further turn. Infundibular part of polykinety (P1) accompanied by other two kineties (P2-3), composed of three parallel rows of kinetosomes each. Three rows of $\mathrm{P} 1$ equal in length and extending to cytostome (Figs 2M, 3R, S). P2 interposed between $\mathrm{P} 1$ and P3. Arrangement of three kinetosomal rows of P2 somewhat staggered: row 1 extends abstomally and considerably longer than rows 2 and 3, terminating adstomally ahead of row 2 and 3 at the last curvature of $\mathrm{P} 1$; row 2 runs parallel with row 1 and separate from row 3 at abstomal half (Figs 2M, 3R). Row 1 of P3 originates from the middle of $\mathrm{P} 2$, while rows 2 and 3 become shortened abstomally. Adstomally P3 converges with P1, both of which terminate at the end of the infundibulum (Figs 2M, 3R, S). Epistomial membrane 1 located near the entrance of infundibulum (Figs 2M, 3R). Epistomial membrane 2 short, located ahead of the beginning of polykinety and haplokinety (Figs 2M, $3 R$ ). Trochal band encircling body equatorially. Germinal kinety parallel to haplokinety, ending at last curve of haplokinety (Figs 2M, 3R).

Thuricola kellicottiana (Stokes 1887) Kahl, 1935 (Figs 4A-Q, 5A-T, Table 1)

1884 Thuricola innixa Stokes, 1882-Kellicott, Proc. Amer. Soc. Microsc., Seventh Annual Meeting., 6: p. 120, Pl.3: Fig. 5.

1887 Thuricolopsis kellicottiana spec. nov.-Stokes, Proc. Amer. Soc. Microsc., p. 251, Fig. 17.

1888 Thuricolopsis kellicottiana Stokes, 1887Stokes, J. Trenton Nat. Hist. Soc., p. 253-254, pl. 9: Fig. 12.

1904 Cothurnia crystallina Ehrbrg.-Entz, Mat. Naturwiss. Ber. Ungarn., 19: p. 140-141, Fig. 10g.

1914 Cothurnia castellensis-Penard, Mém. Soc. Phys. Hist. Nat. Genève, 37: p. 59-60, Pl. 3, Figs 9-11, $13,14$. 


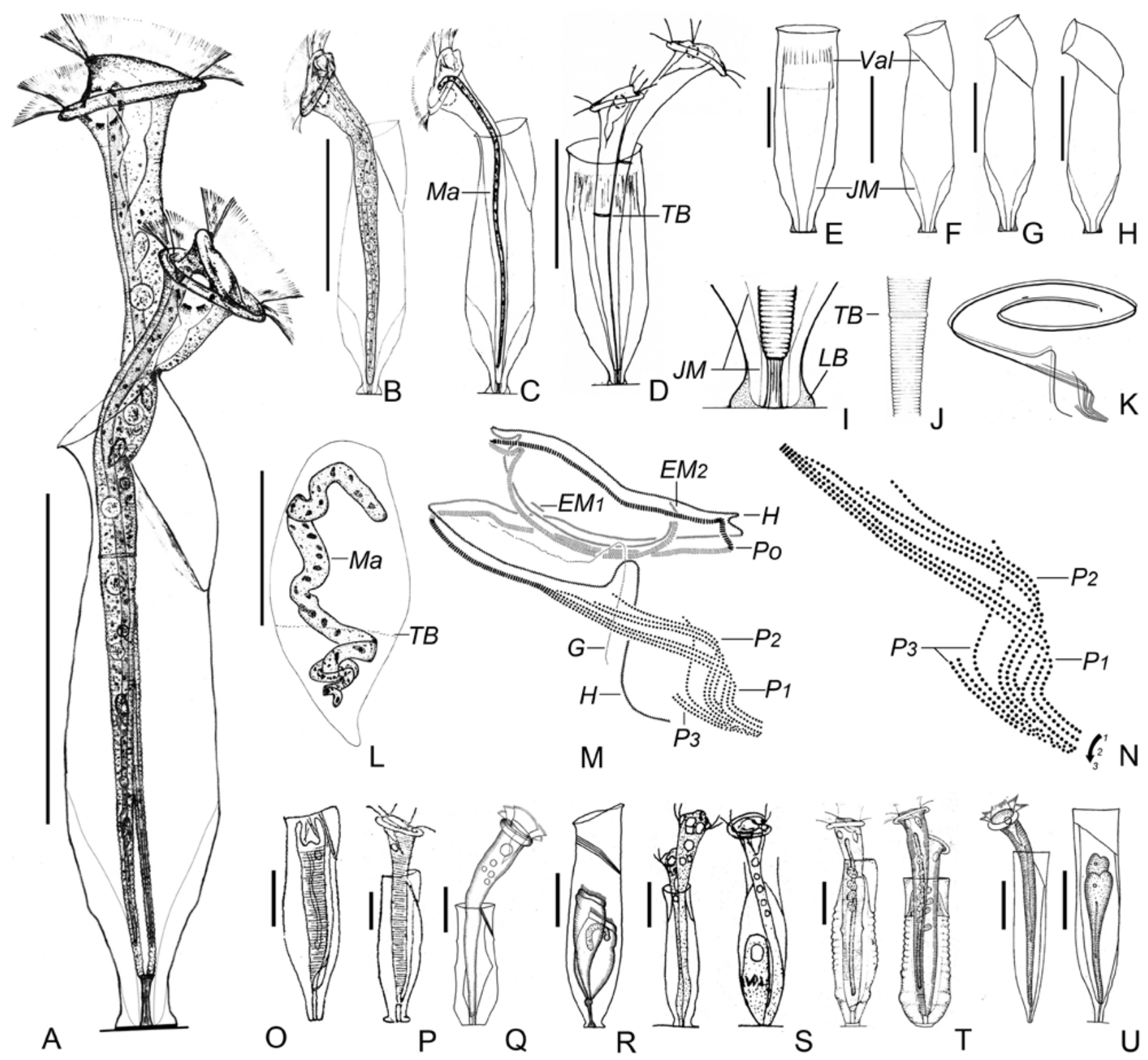

Fig. 2. Morphology and ciliature of Thuricola obconica. (A) Narrow side view of an individual with two zooids. (B) Narrow side view of an individual with single zooid. (C) Narrow side view of an individual with single zooid, to show macronucleus. (D) Wide side view of an individual with two zooids. (E) Wide side view of lorica. (F-H) Narrow side view of different curved lorica. (I) Base of lorica. (J) Detail of pellicle, to show the transverse striations and trochal band. (K) Model pattern of oral ciliature. (L) Macronucleus after protargol staining. (M) Oral ciliature. (N) Detail of infundibular polykineties. (O) T. obconica from Kahl (1933). (P) T. obconica from Kahl (1935). (Q) T. obconica from Bock (1952). (R) T. kamptostoma from Bock (1952) (synonym of T. obconica). (S) T. obconica from Biernacka (1963) (possible misidentification). (T) T. obconica from Küsters (1974) (probably misidentified). (U) T. obconica from Shen \& Gu (2016). EM1-2, epistomial membrane 1-2; G, germinal kinety; H, haplokinety; JM, junctional membrane; LB, lorica base; Ma, macronucleus; Po, polykinety; P1-3, infundibular polykineties 1-3; TB, trochal band; Val, valve. Scale bars $=100 \mu \mathrm{m}(\mathrm{A}, \mathrm{B}, \mathrm{D}) ; 50 \mu \mathrm{m}(\mathrm{E}-\mathrm{H}, \mathrm{L}, \mathrm{O}-\mathrm{U})$. 


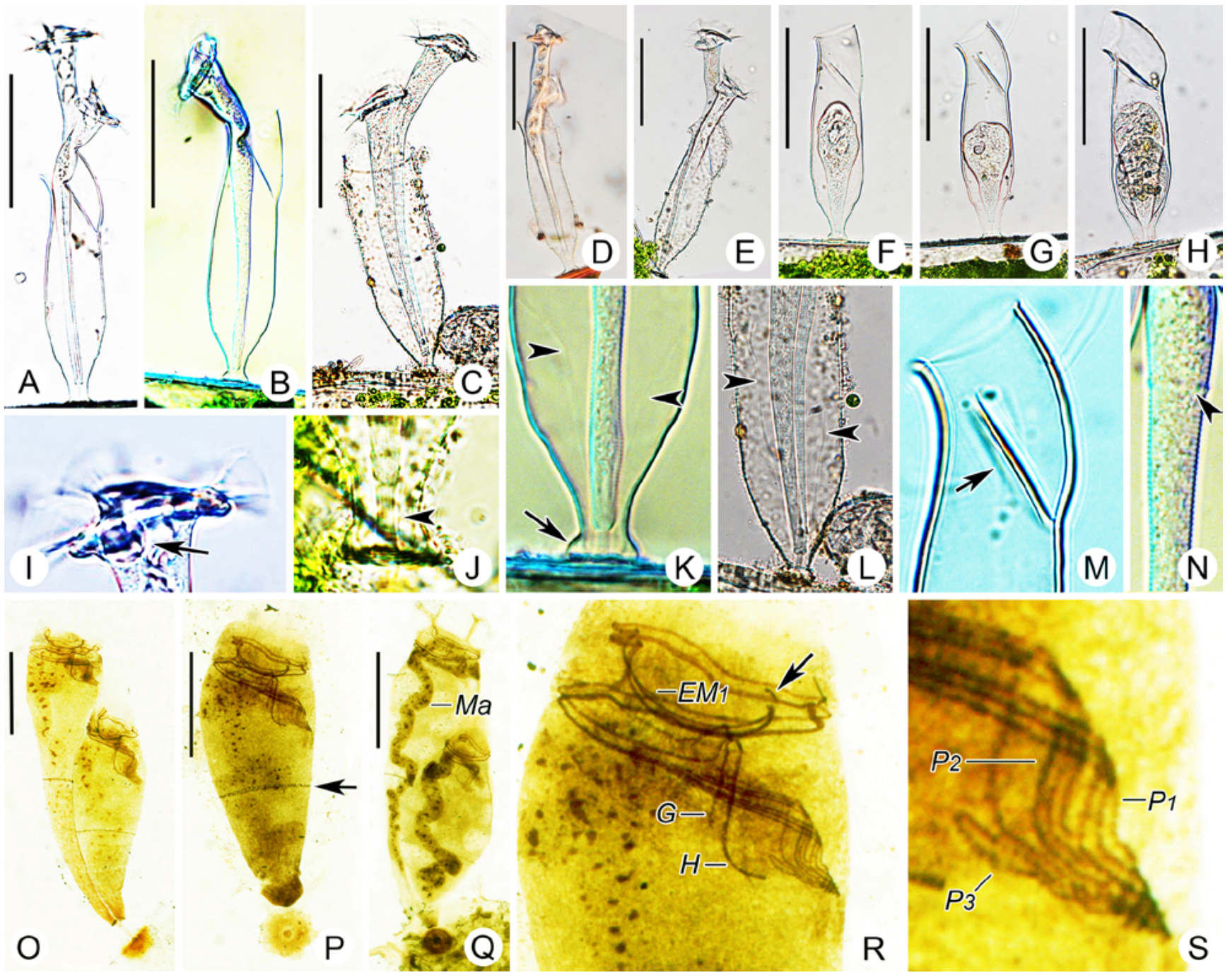

Fig. 3. Photomicrographs of Thuricola obconica from life (A-N) and after protargol staining (O-S). (A) Narrow side view of an individual with two zooids. (B) Narrow side view of an individual with single zooid. (C) Wide side view of an individual with two zooids. (D, E) Narrow side view of different individuals. (F-H) Narrow side view of different curved loricas. (I) Anterior portion of body, arrow marks contractile vacuole. (J) Posterior portion, arrowhead marks junctional membrane around the inner stalk. (K) Posterior portion, arrow marks the expanded lorica base, arrowheads mark the junctional membrane. (L) Wide side view of lorica, arrowhead marks the junctional membrane. (M) Narrow side view of anterior portion of lorica, arrow marks valve. (N) Detail of pellicle, arrowhead marks aboral trochal band. (O-Q) Ciliature of three specimens, arrow marks trochal band. (R) Oral ciliature, arrow marks the epistomial membrane 2. (S) Detail of infundibular polykineties 1-3. EM1, epistomial membrane 1; G, germinal kinety; H, haplokinety; Ma, macronucleus; P1-3, infundibular polykineties $1-3$. Scale bars $=100 \mu \mathrm{m}(\mathrm{A}-\mathrm{H}) ; 50 \mu \mathrm{m}(\mathrm{O}-\mathrm{Q})$.

1922 Cothurnia kellicottiana Stokes-Penard, Georg \& Cie, Genève, p. 290, Fig. 272.

1935 Thuricola (Thuricolopsis) kellicottiana (Stokes 1887)-Kahl, Tierwelt Dtl., p. 785, Fig. 145: 5-6. 1951 Thuricola amphora n. sp.-Sommer, Arch. Hydrobiol., p. 410-411, P1. 20, Fig. 36.

1970 Thuricola kellicottiana (Stokes 1887) Kahl, 1935-Nusch, Arch. Hydrobiol., 37: p. 313, Fig. 33.
1971 Thuricola amphora Sommer, 1951-Stiller, Peritricha. Fauna Hung., 105: p. 214, Fig. 131c.

1980 Thuricola kellicottiana (Stokes 1887) Kahl, 1935-Trueba, Beaufortia, 30: p. 131-132, Figs 2e, 3c, d.

1982 Thuricola kellicottiana (Stokes 1887) Kahl, 1935-Bernerth, Cour. Forsch.-Inst. Senckenberg., 57: p. 170.

1988 Thuricola kellicottiana (Stokes 1887) Kahl, 1935-Foissner, Hydrobiologia, 166: p. 44 (record only). 


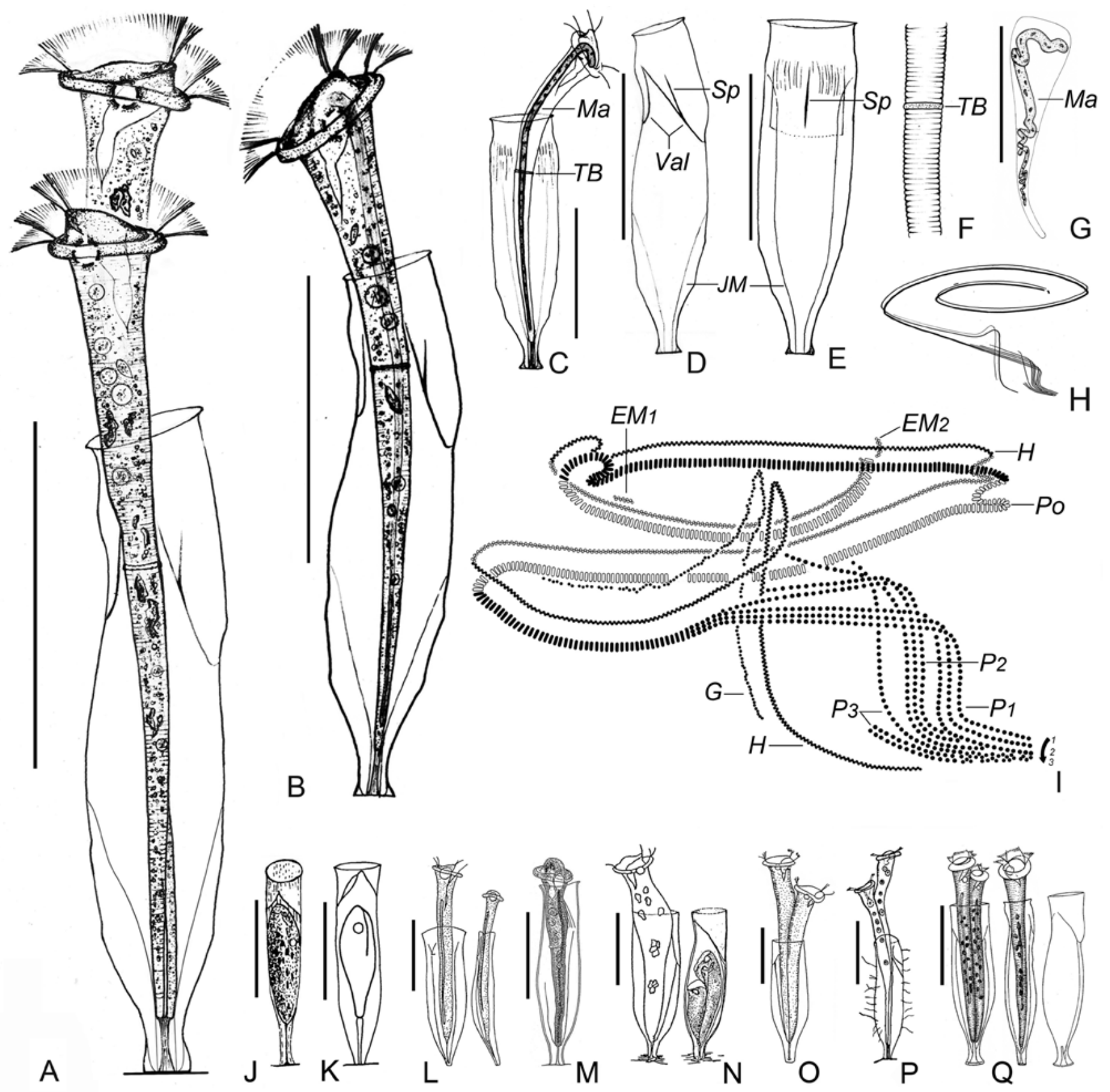

Fig. 4. Morphology and ciliature of Thuricola kellicottiana. (A) Narrow side view of an individual with two zooids. (B) Narrow side view of an individual with single zooid. (C) Wide side view of an individual with single zooid, to show macronucleus in vivo. (D) Narrow side view of lorica. (E) Wide side view of lorica. (F) Detail of pellicle, to show the transverse striations and aboral trochal band. (G) Macronucleus after protargol staining. (H) Model pattern of oral ciliature. (I) Oral ciliature. (J) T. innixa from Kellicottiana, 1884. (K) Thuricolopsis kellicottiana from Stokes, 1887. (L) Cothurnia castellensis from Penard, 1914. (M) T. amphora from Sommer, 1951. (N) T. kellicottiana from Bernerth, 1982. (O) T. kellicottiana from Nusch, 1970. (P) T. kellicottiana from Trueba, 1980. (Q) T. kellicottiana from Shen and Gu (2016). EM1-2, epistomial membrane 1-2; G, germinal kinety; H, haplokinety; JM, junctional membrane; Ma, macronucleus; Po, polykinety; P1-3, infundibular polykineties 1-3; Sp, spine; TB: trochal band; Val, valve. Scale bars $=100 \mu \mathrm{m}$. 


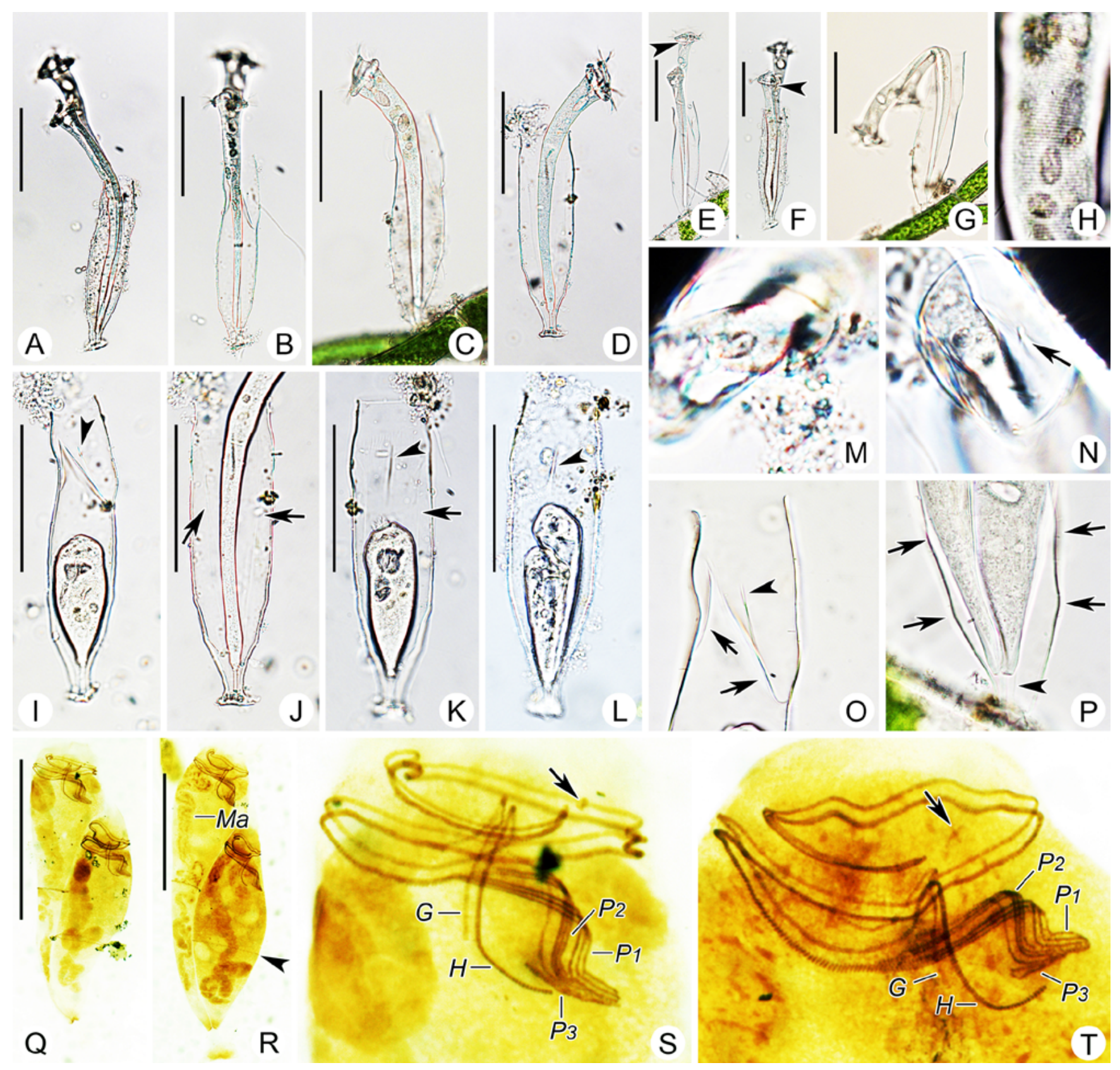

Fig. 5. Photomicrographs of Thuricola kellicottiana in vivo (A-P) and after protargol staining (Q-T). (A-C) Narrow side view of individuals with two zooids (A, B) and single zooid (C). (D) Wide side view of a single zooid individual. (E-G) Narrow side views of different individuals, arrowheads mark contractile vacuoles. (H) Detail of pellicle, to show the transverse striations. (I) Narrow side view of lorica, arrowhead marks the valve spine. (J-L) Wide side view of lorica, arrows mark junctional membrane, arrowheads mark valve spine. (O) Narrow side view of anterior portion of lorica, arrows mark valves, arrowheads marks valve spine. (P) Posterior portion, arrows mark the bulge in the lorica, arrowhead marks junctional membrane around the inner stalk. (Q, R) Ciliature of two specimens, arrowhead marks trochal band. (S) Oral ciliature, arrow marks epistomial membrane 2. (T) Detail of infundibular polykinety 1-3, arrow marks epistomial membrane 2. G, germinal kinety; H, haplokinety; Ma, macronucleus; P1-3, infundibular polykineties $1-3$. Scale bars $=100 \mu \mathrm{m}$. 
1992 Thuricola kellicottiana (Stokes 1887) Kahl, 1935-Foissner et al., Landesamtes Wasserwirtsch., 278-280.

2016 Thuricola kellicottiana (Stokes 1887) Kahl, 1935-Shen \& Gu, Fauna Sinica, Invertebrata, 45: p. 333-334. Pl. CLI, Fig. 456a-e.

Although Thuricola kellicottiana had been reported several times, studies have not been thorough and its morphology remains vague (Stokes 1887). Thus, a redescription is necessary for the sake of clarification.

Emended diagnosis: Lorica colourless and ca. 160-290 $\mu \mathrm{m}$ long, elliptical to sub-circular in crosssection, nearly symmetrical on wider side and asymmetrical on narrower side. Two anisometric valves in upper third of lorica, larger valve with a spine in the middle; anterior third portion inclined with convex under aperture on secondary valve side, posterior portion tapering to base with two annular bulges to form a long slender rear; aperture clearly elliptical, base expanded. Zooid ca. $180-435 \times 20-35 \mu \mathrm{m}$ in vivo. Stalk about 15 $\mu \mathrm{m}$ long. Peristomial lip single-layered and strongly everted. Contractile vacuole dorsally located. Row 1 in infundibular polykinety 3 about twice the length of the other two. Transverse silverlines numbering 95-105 from peristome to trochal band, 100-110 from trochal band to scopula.

Voucher slides: Two voucher slides with protargol stained specimens (registration number: LU2017031003-01-02) have been deposited in the Laboratory of Protozoology, Ocean University of China.

Description: One or two trumpet-shaped zooids that taper towards the scopula, $230-380 \times 20-30 \mu \mathrm{m}(\mathrm{n}=9)$ in vivo (Figs 4A-C, 5A-G). Zooid very flexible and can bend extensively (Fig. 5G). When disturbed, zooid contracts and becomes ellipsoid or broadly conical in outline (Fig. 5I, K, J). Single-layered peristomial lip relatively thin and conspicuously everted, about $40-48 \mu \mathrm{m}$ across (Figs 4A-C, 5A-G). Peristomial disc obliquely elevated above persitome (Figs $4 \mathrm{~A}-\mathrm{C}, 5 \mathrm{~A}-\mathrm{G}$ ). Trochal band forming a circular bulge in mid-region of zooid (Fig. 4C, F). About 95-105 striations from peristome to trochal band and 100-110 striations from trochal band to scopula (counted from live cells, $\mathrm{n}=5$ ).

One contractile vacuole located at the same level as peristomial lip and on the dorsal wall of infundibulum (Figs 4A, 5E, F). Cytoplasm hyaline and contains numerous small granules and several food vacuoles (Figs 4A, B , 5A-G). Food vacuoles spindle-shaped when freshly detached from cytostome.
Macronucleus vermiform, extends almost entire length of zooid, relatively straight but curved transversely above peristomial lip, widens gradually towards anterior end (Figs 4C, G, 5Q, R). Due to shrinkage during fixation, macronucleus in protargol stained specimens is more twisted than in vivo (Figs $4 \mathrm{G}, 5 \mathrm{Q}, \mathrm{R}$ ).

Stalk about $15 \mu \mathrm{m}$ long in average, both ends slightly expanded (Figs 4A-C, 5A-G).

Lorica hyaline, about $190-225 \mu \mathrm{m}$ long. Narrow side about $44-50 \mu \mathrm{m}$ across and wide side about $51-54$ $\mu \mathrm{m}$ across; wall smooth and colourless. Viewed from the narrower side, the upper third portion of lorica inclined (Figs 4A, B, D, 5I, O). Aperture slightly everted and elliptical. Lorica conspicuously convex under aperture on secondary valve side and with a bulge in region above base of main valve (Figs 4A, B, D, 5I, O). Viewed from the wider side, lorica approximately symmetrical. Posterior region tapering and step-like (Figs 4A-E, 5A-G, I-L, P). Lorica widened at base (Figs $4 \mathrm{~A}-\mathrm{E}, 5 \mathrm{~A}-\mathrm{G}, \mathrm{I}-\mathrm{L}, \mathrm{P})$. One main valve and one secondary valve located in the upper third of lorica. Viewed from the wider side, valves include some longitudinal fibril-like elements (Figs 4C, E, 5K, L). Large main valve curved at base, with central spine that is variable in length (Figs 4D, E, 5I, K, L, N). Secondary valve smaller and easily overlooked (Figs 4D, E, 5I, K, L, O). Main valve connected to inconspicuous junctional membrane (Fig. 5I).

Oral cilia approximately $18 \mu \mathrm{m}$ long. Haplokinety and polykinety commencing together to form a spiral that performs about 1.5 turns around peristomial disc before plunging into infundibulum where they perform a further turn (Figs 4H, I, 5Q-T). Within infundibulum, haplo- and polykineties spiral on opposite walls, terminating at cytostome. The polykinety transforms into three infundibular polykineties (P1-3), each consisting of three parallel rows of kinetosomes (Figs 4L, M, 5S, $\mathrm{T})$. All rows of $\mathrm{P} 1$ are equally long (Figs $4 \mathrm{I}, 5 \mathrm{~S}, \mathrm{~T}$ ). Three rows of $\mathrm{P} 2$ in a staggered arrangement, that is, row 1 commences slightly behind $\mathrm{P} 1$ and terminates just before second turn of $\mathrm{P} 1$; row 2 starts and ends a little behind row 1; the abstomal end of row 3 starts away from row 2 while the adstomal end terminates beyond row 2 (Figs 4I, 5S, T). Row 1 of P3 commences at the middle of $\mathrm{P} 2$ and approximately twice as long as the other two rows; adstomal ends of these three rows disordered (Figs 4I, 5S, T). Epistomial membrane 1 located near the entrance of infundibulum (Fig. 4I). Epistomial membrane 2 ahead of polykinety and 
haplokinety (Figs 4I, 5S, T). Trochal band in mid-region of zooid (Figs 4C, G, 5Q, R). Germinal kinety parallel to haplokinety and ends at last bend of haplokinety (Figs 4I, 5S, T).

\section{Thuricola folliculata Kent, 1881 (Figs 6A-U, 7A-Q, Table 1)}

1881 Thuricola folliculata-Kent, Manual infusoria II., p. 718-719, Pl. XL, Figs 6-8.

1914 Cothurnia regalis-Penard, Mém. Soc. Phys. Hist. Nat. Genève, p. 58-59, Fig. 3: 1-8.

1922 Cothurnia crystallina Ehrenberg, 1838-Penard, Georg \& Cie, Genève, p. 285, Figs 268-271.

1935 Thuricola folliculata (O. F. Müller 1786)-

Kahl, Tierwelt Dtl., 30: p. 785, Fig. 145: 1, 2.

1939 Thuricola folliculata (O. F. Müller, 1786)-

Kudo, Protozoology, second edition, p. 624, Fig. 283 e.

(Recorded in each editions)

1951 Thuricola folliculata (O. F. Müller 1786)

Fromentel-Kent-Sommer, Arch. Hydrobiol., 44: p. 411, Fig. 37a, b.

1951 Thuricola obliqua n. sp.-Sommer, Arch. Hydrobiol., 44: p. 413, Fig. 39.

1962 Thuricola folliculata Kent, 1881-Liebmann, Handbuch der Frischwasser und Abwasser-Biologie I., p. 479, Pl. 14, Fig. 32.

1970 Thuricola folliculata (O. F. Müller 1786)Nusch, Arch. Hydrobiol., 37: p. 31-32, Fig. 32.

1971 Thuricola folliculata Kent, 1881-Stiller, Peritricha. Fauna Hung., 105: p. 214, Fig. 130a, b.

1972 Thuricola folliculata Kent, 1881-Bick, World Health Organization, Geneva, p. 128-129, Fig. 66.

1980 Thuricola folliculata Kent, 1881-Eperson, Protistologica, 16: 549-564, Figs 1-26.

1980 Thuricola folliculata Kent, 1881-Trueba, Beaufortia, 30: 132 (revision).

1983 Thuricola folliculata Kent, 1881-Jiang, Shen \& Gong, Beijing: Science Press., p. 191, Pl. 39, Fig. $335 \mathrm{a}, \mathrm{b}$

1992 Thuricola folliculata Kent, 1881-Foissner et al., Landesamtes Wasserwirtsch. 5/92, 273-277, Figs $1-26$

2016 Thuricola folliculata Kent, 1881-Shen \& Gu, Fauna Sinica, Invertebrata., 45: p. 332. P1. CL, Fig. 453a-c.

Thuricola folliculata is a widespread species first described by Kent (1881) who identified his population as the undefined Vorticella folliculata Müller, 1786 from Cyclops. Based on a careful reading of Müller's original description, however, and the fact that Thurico- la has never been detected epizootically, Trueba (1980) thought Vorticella folliculata sensu Kent (1881) is in fact a species of Thuricola and recognized Kent as the authority for $T$. folliculata. Although T. folliculata has been described many times, taxonomic information is still incomplete and past descriptions are often contradictory. Thus, we here supply a redescription based on two populations.

Emended diagnosis: Lorica colourless, about 125$300 \mu \mathrm{m}$ long, with two valves at upper third; crosssection elliptical to sub-circular, wider side nearly symmetrical, narrower side asymmetrical with a neck at the upper third, aperture elliptical, base expanded. Zooid $165-420 \times 15-27 \mu \mathrm{m}$ in vivo. Stalk usually less than $10 \mu \mathrm{m}$ long. Peristomial lip single-layered and strongly everted. Contractile vacuole dorsally located. Row 1 in infundibular polykinety 3 about two to three times the length of the other two. Transverse silverlines numbering 95-115 from peristome to trochal band, 85-110 from trochal band to scopula.

Voucher slide: A voucher slide with protargol stained specimens of Ningbo population (registration number: LU20170316-01-01) and five voucher slides with protargol stained specimens of Qingdao population (registration numbers: LU20170424-02-01-05) have been deposited in the Laboratory of Protozoology, Ocean University of China.

Description: Morphological data of two populations are in accordance with each other. One or two anisometric zooids about 165-315 × 15-25 $\mu \mathrm{m}(\mathrm{n}=$ $13)$, which live solitarily or coupled with another anisometric zooid in a lorica. If two zooids inhabit the same lorica, when fully extended larger zooid projects nearly one-half its length beyond aperture of lorica, while smaller one usually protrudes almost one-third of its body out of lorica (Figs 6A, C, 7A-C). If solitary, zooid is relatively small (Figs 6B, 7D). Zooid slender, widest at peristomial lip, and flexible, often bending (Fig. 7E-G). Contracted bodies elongate obovate (Fig. $7 \mathrm{H})$. Single-layered, thin peristomial lip protrudes well beyond body, about 36-50 $\mu \mathrm{m}$ in diameter (Figs $6 \mathrm{~A}-\mathrm{C}$, 7A-E). Peristomial disc obliquely elevated above peristome lip (Figs 6A-C, 7A-E). Pellicular striations inconspicuous at low magnifications but distinct at $400 \mathrm{x}$ magnification and higher (Figs 6G, 7M). About 95-115 striations from peristome to trochal band $(n=6)$ and 85-110 striations from trochal band to scopula $(n=8)$. Trochal band forms an inconspicuous bulge near midbody (Figs 6D, G, 7M). 

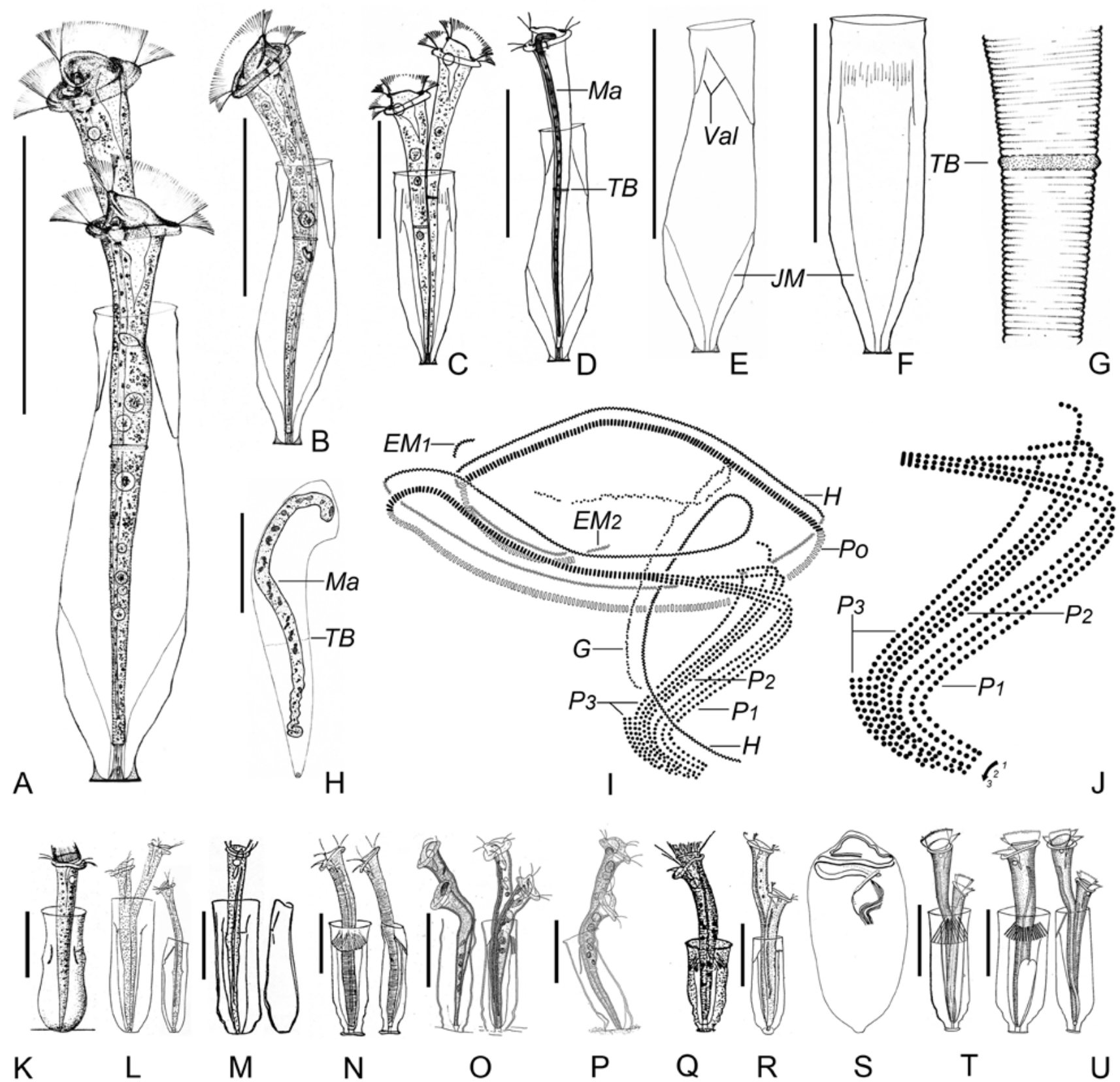

K

$\mathrm{M}$

$\mathrm{N}$

$\mathrm{O}$

Fig. 6. Morphology and ciliature of Thuricola folliculata. (A) Narrow side view of an individual with two zooids. (B) Narrow side view of an individual with single zooid. (C) Wide side view of an individual with two zooids. (D) Macronucleus in vivo. (E) Narrow side view of lorica. (F) Wide side view of lorica. (G) Detail of pellicle, to show the transverse striations and aboral trochal band. (H) Macronucleus after protargol staining. (I) Oral ciliature. (J) Detail of infundibular polykineties. (K) T. folliculata from Kent (1881). (L) Cothurnia regalis from Penard (1914) (synonym of T. folliculata). (M) Cothurnia crystallina from Penard (1922) (synonym of T. folliculata). (N) T. folliculata from Kahl (1935). (O) T. folliculata from Sommer (1951). (P) T. obliqua from Sommer (1951). (Q) T. folliculata from Liebmann (1962). (R) T. folliculata from Nusch (1970). (S) Ciliature of T. folliculata from Eperson (1982). (T) T. folliculata from Jiang et al. (1983). (U) T. folliculata from Shen and Gu (2016). EM1-2, epistomial membrane 1-2; G, germinal kinety; H, haplokinety; JM, junctional membrane; Ma, macronucleus; Po, polykinety; P1-3, infundibular polykineties 1-3; TB, trochal band; Val, valve. Scale bars $=100 \mu \mathrm{m}$. 


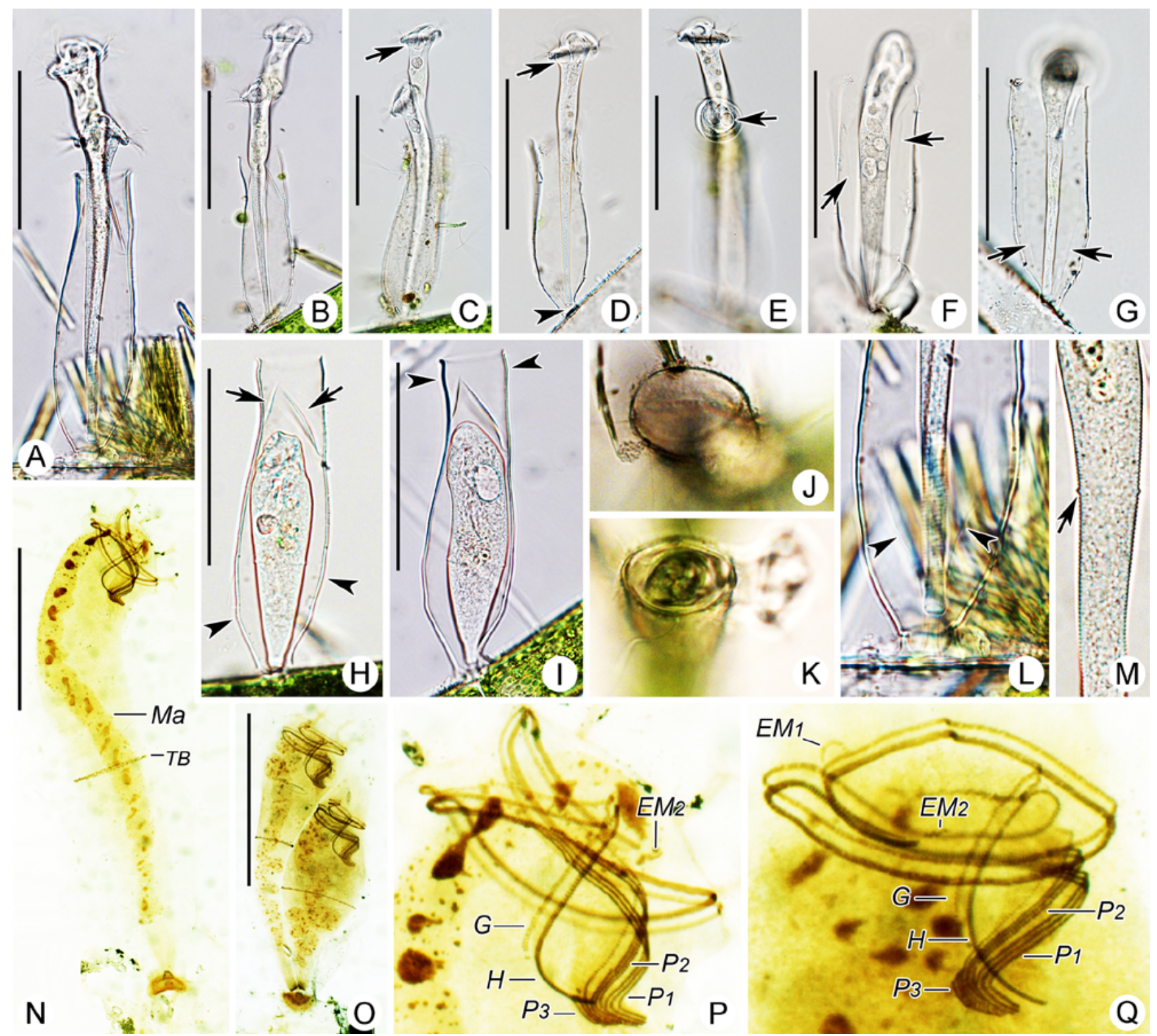

Fig. 7. Photomicrographs of Thuricola folliculata in vivo (A-M) and after protargol staining (N-Q). (A-E) Narrow side views of different individuals with two zooids (A-C, E) and single zooid (D), arrows mark contractile vacuole. (F, G) Wide side views of lorica, arrows mark the junctional membrane. (H, I) Narrow side views of lorica, arrows in $\mathrm{H}$ mark valves, arrowheads in $\mathrm{H}$ mark posterior bulge of lorica, arrowheads in (I) mark anterior bulge of lorica. (J, K) Aperture of lorica. (L) Posterior portion of lorica, arrowheads mark junctional membrane. (M) Detail of pellicle, to show the transverse striations, arrow marks the aboral trochal band. (N, O) Ciliature of two specimens. (P, Q) Oral ciliature. EM1-2, epistomial membrane 1-2; G, germinal kinety; H, haplokinety; Ma, macronucleus; P1-3, infundibular polykineties $1-3$; TB, trochal band. Scale bars $=100 \mu \mathrm{m}$.

Contractile vacuole located at the level of peristomial lip near dorsal wall of infundibulum (Figs 6A, 7C-E). Cytoproct not observed. Endoplasm highly granulated with a few fusiform or globular food vacuoles (Figs 6A-C, 7A-D), usually scattered in the anterior portion of body.
Macronucleus vermiform extending almost entire length of zooid (Figs 6D, H, 7N, O), rather hyaline, and invisible in vivo. Due to significant shrinkage in the fixation process, macronucleus highly twisted in most of protargol stained samples (Fig. 7O). One extended individual was obtained in protargol preparations, which 
revealed that main section of macronucleus to be relatively straight with anterior section curved transversely, gradually widening towards top (Figs $6 \mathrm{D}, 7 \mathrm{~N}$ ).

In 12 investigated samples, only one individual had a $13 \mu \mathrm{m}$ long stalk, while stalks of the others being less than $10 \mu \mathrm{m}$ long: on average, $7.3 \mu \mathrm{m}$ long in Ningbo population and $4.6 \mu \mathrm{m}$ long in Qingdao population. Two ends of stalk slightly widened (Figs 6A-E, 7A, D).

Lorica about $125-190 \mu \mathrm{m}$ tall, with colourless wall. Lorica nearly symmetrical and about 48-52 $\mu \mathrm{m}$ wide on its wider side (Figs 6C, F, 7F, G), asymmetrical and about $39-51 \mu \mathrm{m}$ wide on its narrower side. Viewed from the narrower side, lorica reaches its greatest width at the posterior third and neck-like at the anterior third (Figs 6E, 7H, I). Aperture slightly everted and elliptical (Figs 6E, 7H, I). Usually with a convex ring immediately under aperture (Figs 6E, 7H, I). Rear third conical tapered with two annular bulges (Figs 6A-F, 7A-D, H, I). Lorica base expanded (Figs 6A-F, 7H, I, L). Two valves in anterior third of lorica, one large (main) and one small (secondary) (Figs 6A, B, D, E, 7A-D, H, I). One larger main valve and one smaller secondary valve. Both valves contain some longitudinal fibriform elements (Figs 6C, F, 7F, G). Base of main valve bent (Figs 6E, 7H, I).

Oral ciliature largely resembles previous two species in this study. Haplokinety and polykinety make approximately a 1.5 turn around peristome and a further circuit on opposite walls inside infundibulum (Figs 6I, 7N-Q). P1-P3 composed of three distinct rows of kinetosomes each (Figs 6I, J, 7N-Q). P1 bends twice and comprises three equally long rows (Figs 6I, J, 7N-Q). $\mathrm{P} 2$ ends near second bend of $\mathrm{P} 1$ and between $\mathrm{P} 1$ and $\mathrm{P} 3$. Three rows of P2 also form a staggered pattern, i.e. row 1 commences and terminates before row 2 ; row 3 starts and ends a little behind row 2, with abstomal end detached from rows 1 and 2 (Figs 6I, J, 7N-Q). P3 converges with $\mathrm{P} 1$ at adstomal end. Row 1 of P3 extremely long, about twice to three times as long as two other rows (Figs 6I, J, 7N-Q). Epistomial membrane 1 short, located near opening of infundibulum (Figs 6I, 7Q). Epistomial membrane 2 located before haplo- and polykinety (Figs 6I, 7P, Q). Trochal band in mid-region of zooid. Infundibular part of haplokinety accompanied by germinal kinety until its last curve (Figs $6 \mathrm{H}, 7 \mathrm{~N}, \mathrm{O}$ ).

Molecular data and phylogeny: The new SSU rDNA sequences of these three species have been deposited in the GenBank database with length (bp), GC content and GenBank accession numbers as follows: T. obconica - 1,592, 42.46\%, MH035973; T. kellicot- tiana - 1,596, 42.11\%, MH035974; T. folliculata $1,605,42.12 \%$, MH035975. There were no differences between the SSU rDNA sequences of the two populations of T. folliculata (Ningbo pop I and Qingdao pop II), thus only pop I's (Ningbo) data was deposited in the GenBank database. The sequence of T. obconica differs from T. folliculata and T. kellicottiana in two and nine nucleotides, respectively. T. folliculata differs from T. kellicottiana in seven nucleotides.

The phylogenetic trees inferred from the SSU rDNA sequences using ML and BI methods resulted in the same topologies, therefore, only the ML tree (with nodal support from both methods) is shown (Fig. 8). The three species of Thuricola clustered together with a putative species of Vaginicola (KU363269, star) (62\% ML, $0.77 \mathrm{BI}$ ), and then grouped with other Vaginicola species and the genus Usconophrys to form a sister clade $(40 \% \mathrm{ML}, 0.60 \mathrm{BI})$ to the clade of cothurnids $(63 \% \mathrm{ML}, 0.80 \mathrm{BI})$, thus falling within the clade of loricate sessilids (Vaginicolidae, Usconophryidae) and clearly distinct from other taxa without lorica.

\section{DISCUSSION}

Comments on the genus Thuricola: Since it was erected by Kent (1881) dozens of nominal species have been reported. In many earlier studies, however, the information necessary for species circumscription, such as morphometric data, detailed live features, and ciliature, were frequently insufficiently described or unreported (Kahl 1935, Eperson 1980, Trueba 1980, Foissner et al. 1992, Shen and Gu 2016).

Hitherto, seventeen species were recognized within Thuricola. Prior to this study, T. folliculata, T. valvata Wright, 1858 and T. parafolliculata Sun et al., 2009 were investigated using silver staining methods. Unfortunately, this staining for T. folliculata was unsuccessful (Eperson 1980) and ciliature of T. valvata is dubious because the staining is not clearly enough to confirm the details of P3 (Sun et al. 2009).

Interestingly, the ciliature data of the three species in our work (T. obconica, T. kellicottiana and T. folliculata based on present study) and T. parafolliculata are basically congruent. Due to the lack of ciliature data in respect to other congeners, however, we cannot draw any conclusions as to whether this is a coincidence or a phenomenon shared among the Thuricola spp. From our perspective, we would lean towards the latter. The main differences among these three species lie in lorica 


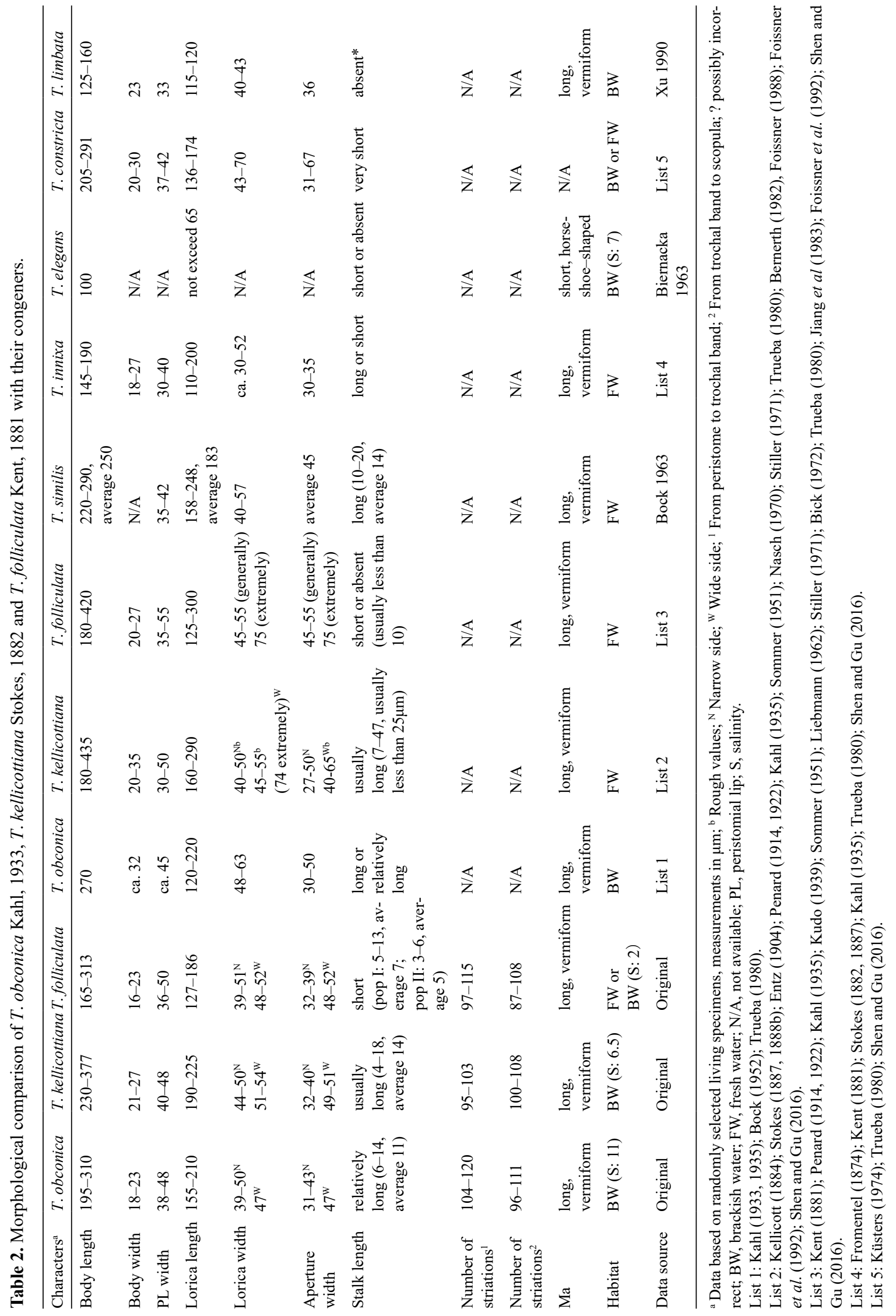


B. Lu et al.

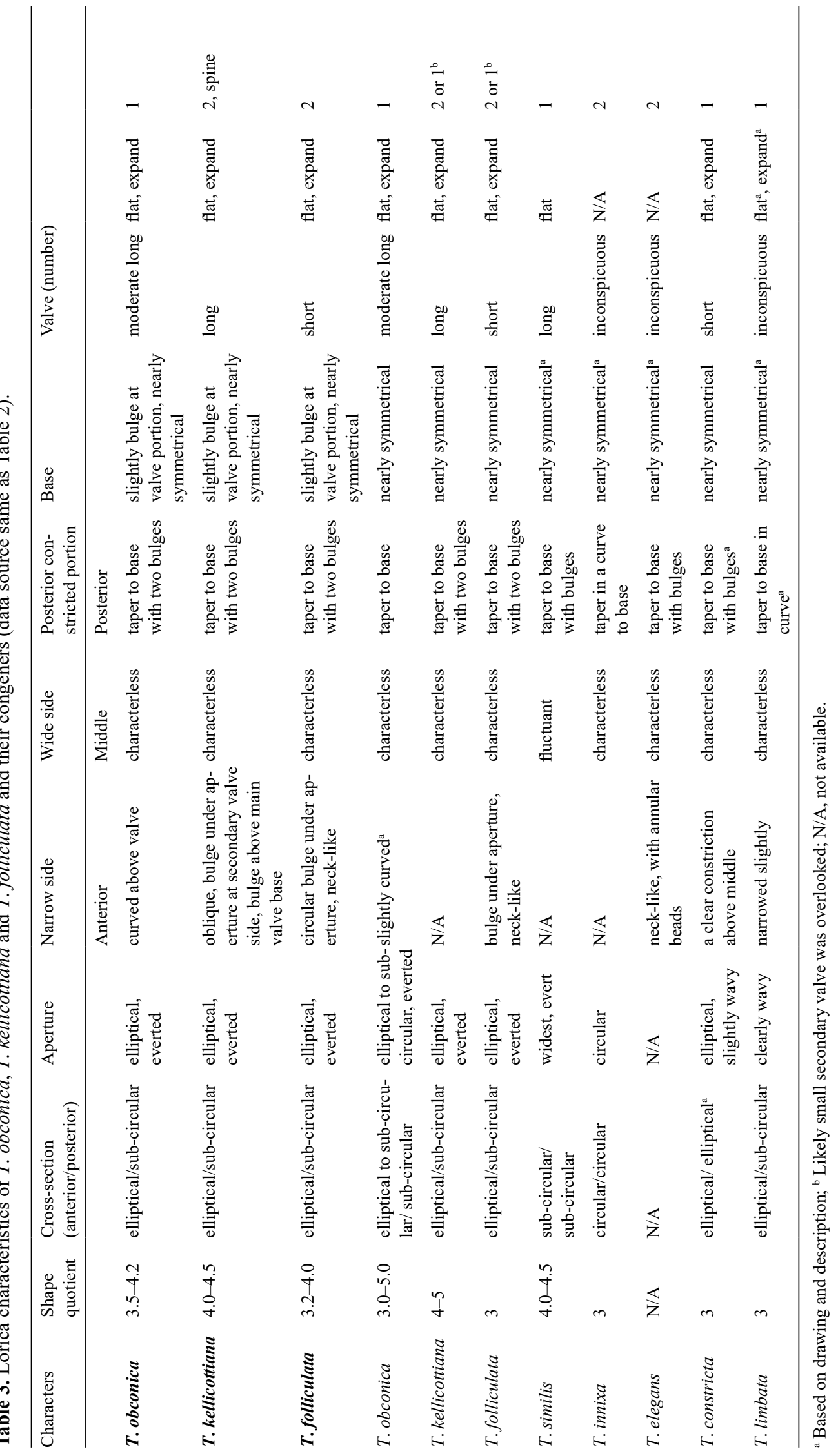




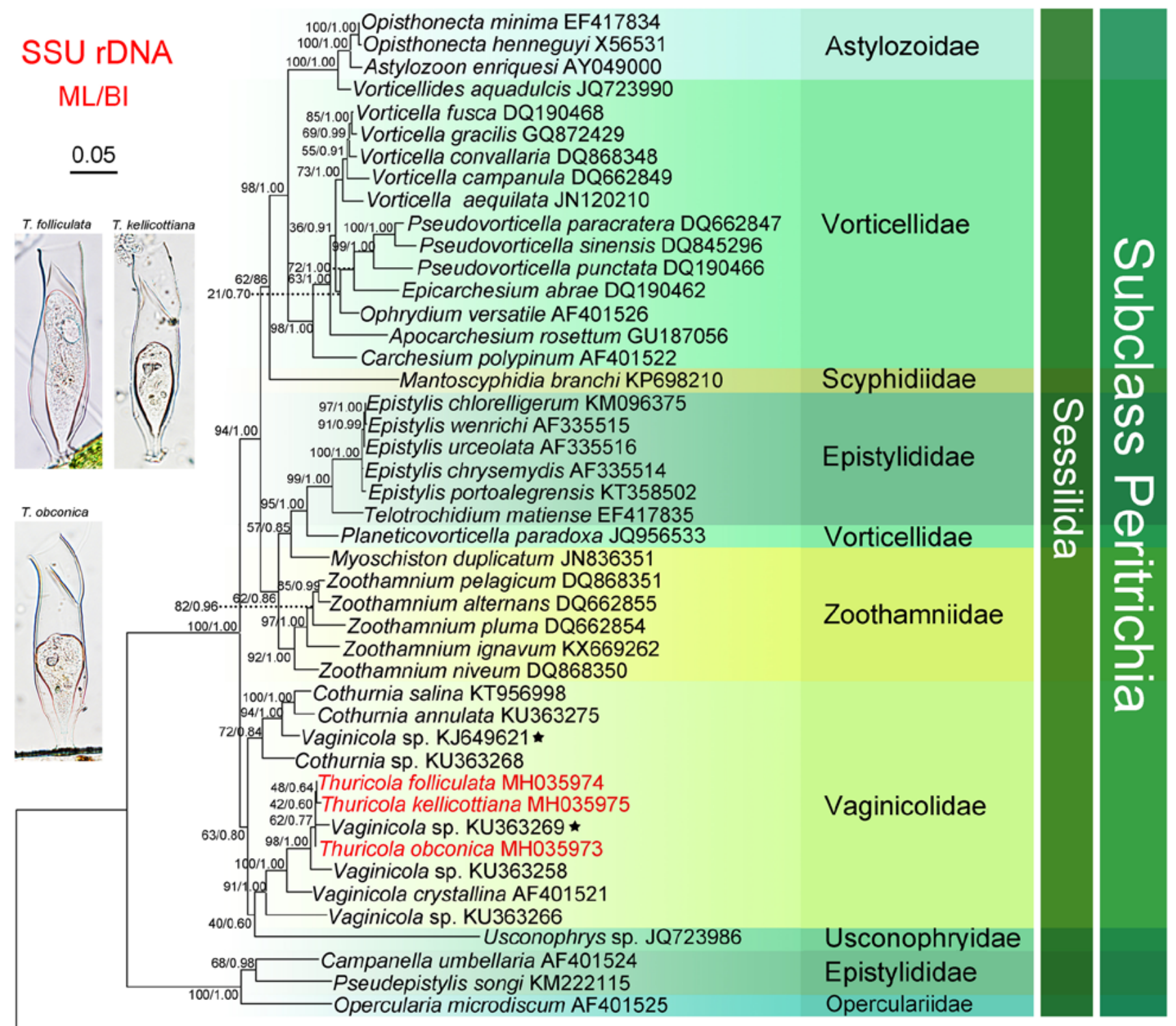
100/1.00 Hymenostomatia

Fig. 8. Phylogenetic tree inferred from SSU rDNA sequences, revealing the phylogenetic positions of Thuricola folliculata, Thuricola kellicottiana and Thuricola obconica (red fonts). The two sequences marked by stars (KJ649621 and KU363269) are probably misidentified. Numbers near nodes denote Maximum likelihood (ML) bootstrap values and Bayesian inference (BI) posterior probability, respectively. The scale bar indicates five substitutions per 100 nucleotides. Systematic classification follows Sun et al. (2012) and Gao et al. (2016b).

structure. Thus, complete observations of live materials, especially wider and narrower side views of lorica, are extremely important for species separation in vaginicolids.

Some literatures once state the JM is a semi-cylindrical cuticle, which is probably incorrect. Our work demonstrates it cannot be semi-cylindrical, because its posterior portion possesses a circular cross-section defi- nitely. Furthermore, rear-end of JM connects to bottom of lorica rather than the aboral end of zooid as reported by some previous work.

Comments on Thuricola obconica: T. obconica was originally reported by Kahl (1933) from brackish water in Bottsand near Kiel, Germany. He later added more information on this species (Kahl, 1935). Bock (1952) reported two species from brackish water, namely 
T. obconica and T. kamptostoma. The lorica of the former is plumper than that of Kahl's form. According to Bock's description, T. kamptostoma has a lorica that is slimmer, longer and smoother than that of T. obconica; otherwise, however it resembles Kahl's report of T. obconica, and we therefore followed Trueba's (1980) proposal to recognize T. kamptostoma as a synonym of T. obconica.

Biernacka (1963) and Küsters (1974) also described brackish water populations of $T$. obconica. Their figures and descriptions did not accord well with Kahl's report, however. From Biernacka's drawing, his population has two valves rather than the one valve in Kahl's report. Küsters indicated that there are annular ridges in the middle portion of the lorica, which does not occur in the original population. Therefore these two thuricolas cannot be T. obconica. Recently, Shen and Gu (2016) reported a freshwater form under the name of T. obcon$i c a$, but the lorica in this form is not curved above the valve (from the drawing). Thus, it is probably distinct species of Thuricola.

Our population matches well with Kahl's description in basic morphological characters (cell and lorica size, valve number and inner stalk length) and habitat (brackish water). Although Kahl did not describe the lorica curve above the valve, he did illustrate this character. It is therefore reasonable for us to identify our form as T. obconica (Kahl 1933, 1935; Trueba 1980).

Within the genus Thuricola, only four species, namely T. obconica Kahl, 1933, T. elegans Biernacka, 1963, T. constricta Küsters, 1974 and T. limbata Xu, 1990, have been found in brackish water habitats. T. obconica can be easily distinguish from the others by its distinctive feature: i.e. that the lorica is clearly curved above the valve.

Compared to T. elegans, T. obconica is separated by its longer lorica $(155-210 \mu \mathrm{m}$ vs. less than $65 \mu \mathrm{m})$, number of valves ( 1 vs. 2 ) and the shape of the macronucleus (long and vermiform vs. short and horseshoelike) (Biernacka 1963).

$T$. constricta differs from $T$. obconica mainly by a clear constriction above the middle portion, which is lacking in T. obconica (Küsters 1974, Trueba 1980).

T. limbata is distinguished from T. obconica by the shape of the lorica: the aperture is circular and clearly wavy and not bent in the front of the valve (Xu 1990).

The population of $T$. kellicottiana reported in this paper was also isolated from a brackish water habitat. It, however, has two valves and a spine in the middle of the main valve, and thus it cannot be conspecific with T. obconica.
Comments on Thuricola kellicottiana: Based on the revision of Trueba (1980), so far Thuricola kellicottiana had been investigated for at least fifteen times, however its taxonomic characteristics are still incomplete. In the literature, the descriptions of this species are often contradictory, especially in respect to whether there are one or two valves. Since the secondary valve is small, we believe that it may have been overlooked in some previous studies. After comparing our population with all valid thuricolas, we identify it with $T$. kellicottiana because it is consistent with the reports in the literature in terms of the basic morphology (zooid size, lorica size, strongly constricted lorica tail, long inner stalk and two valves), even though the inconspicuous spine in the middle of main valve has not been mentioned previously (Kellicott 1884; Stokes 1887, 1888b; Penard 1914, Kahl 1935, Sommer 1951, Nusch 1970, Stiller 1971, Trueba 1980, Bernerth 1982, Foissner et al. 1992, Shen and Gu, 2016).

Thuricola kellicottiana has previously been found only in fresh water whereas our population was collected from brackish water (salinity $6.5 \%$ ). This species is characterized by its closure apparatus: one larger valve with a spine in the middle and one smaller valve. Only three other thuricolas, namely $T$. folliculata, $T$. innixa Stokes, 1882 and T. elegans Biernacka, 1963, have previously been reported as having two valves. These valves, however, lack a spine. Considering that this tiny structure is easily overlooked, the presence or absence of a spine is not enough to differentiate $T$. kellicottiana from these other species. It is also noteworthy that since the smaller secondary valve is also easily overlooked, it is not clear whether it is also present in some thuricolas that have previously been reported as only having one valve. T. kellicottiana can be distinguished from most of these other species by its long inner stalk except $T$. similis.

The shape of the lorica of $T$. folliculata is different from T. kellicottiana, in the former this is usually a convex ring occurring immediately under the aperture, whereas in the latter it is obviously convex at the secondary valve side with a bulge occurring on the base of the main valve.

T. innixa is a poorly known species, but its inner stalk is short or absent compared to the usually long stalk in T. kellicottiana. Besides, the base of the lorica is rounded and tapered in a curve while it is strongly constricted and tapered step-like in T. kellicottiana (Stokes 1882, 1888a).

T. elegans can be distinguished from T. kellicottiana by the much smaller lorica (less than $65 \mu \mathrm{m}$ long vs. 
190-225 $\mu \mathrm{m}$ long), the shape of macronucleus (short and horseshoe-like vs. long and vermiform) (Biernacka 1963).

T. similis is similar to T. kellicottiana in its inner stalk length but it only has one valve (vs. two) and is found in activated sludge (vs. fresh or brackish water) (Bock 1963).

Comments on Thuricola folliculata: $T$. folliculata is a widespread species that has been reported many times. Our population corresponds well with previous descriptions in the lorica structure and macronucleus shape, stalk length and zooid size. As with T. kellicottiana, there is again an inconformity in the number of valves reported in the literature. Consistent with a few previous studies, our population consistently has two valves in the lorica (Penard 1922). Most researchers, however, report only one valve in the lorica (Kent 1881, Penard 1922, Kahl 1935, Kudo 1939, Sommer 1951, Liebmann 1962, Nusch 1970, Bick 1972, Trueba 1980, Jiang et al. 1983, Foissner 1992; Shen and Gu 2016). Considering that the secondary valve is small, possibility of neglect cannot be excluded.

Up to now, eleven thuricolas were founded in fresh water. Besides T. folliculata, two of these species definitely possess two valves: T. kellicottiana and $T$. innixa. As mentioned above, T. kellicottiana differs from T. folliculata in its lorica shape and stalk length. T. innixa can also be distinguished from $T$. folliculata by its lorica shape: tapering to the base in a curve (vs. steplike) and circular cross-section (vs. clearly elliptical in the front third portion) (Fromentel 1874, Kent 1881, Stokes 1887, Penard 1914, Kahl 1935, Trueba 1980).

We followed Trueba (1980) to treat the following forms as synonyms of Thuricola folliculata: Cothurnia regalis reported by Penard (1914), Cothurnia crystallina sensu Penard (1922) and Thuricola obliqua Sommer, 1951.

Phylogenetic analysis: As previous studies have shown (Sun et al. 2016, Zhuang et al. 2016), the loricate sessilids (Vaginicolidae and Usconophryidae) formed a branch separated from the aloricate sessilids even though the confidence value was relatively low $(63 \% \mathrm{ML}, 0.80 \mathrm{BI})$. Considering that the addition of three new sequences of Thuricola in this study has reduced the support for this branch, additional new sequences are needed in order to reveal the true phylogenetic relationships within the loricate sessilids.

In terms of the loricate group, the Vaginicolidae is formed of two sub-clades: Cothurnia spp. together with Vaginicola sp. (KJ649621, star) (possibly misidentified) form one sub-clade, while the other vaginicolids group into the other sub-clade, which it sister to Usconophrys. Since Cothurnia has a stalk outside the lorica while other vaginicolids and Usconophrys lack this stalk, this structure is probably a key character for the evolution of vaginicolids. Strangely, our three thuricolas group with Vaginicola sp. (KU363269, star). Considering this sequence (KU363269) was obtained from environmental sequencing without morphological information, it cannot be excluded that this species was misidentified.

To date, about two hundred nominal species have been assigned in the family Vaginicolidae, however, the SSU rDNA sequences are only available for eight taxa. Furthermore, only one species (Cothurnia salina) has thorough taxonomic data; most other sequence data were based on ecological samples without species identities, leaving open the possibility that there have been some misidentifications and synonyms. It is also possible that the present topology is biased due to limited taxon sampling. Additional sequences of vaginicolids are required in order to construct a more robust phylogeny for this complex group.

Acknowledgements. This work was supported by the Natural Science Foundation of China (project numbers: 41576134, 31772413, 31572230), the Fundamental Research Funds for the Central Universities (project No. 201762017) and the Deanship of Scientific Research at King Saud University (PRG-1436-24). We thank specially the two reviewers of this paper revised the manuscript and made several very constructive criticisms.

\section{REFERENCES}

Bernerth, I. (1982) Ökologische untersuchungen im kühlwassersystem eines konventionellen Großkraftwerks am untermain unter besonderer berücksichtigung der ciliaten (Protozoa). Cour. Forsch.-Inst. Senckenberg. 57: 1-246

Bick H. (1972) Ciliated protozoa: an illustrated guide to the species used as biological indicators in freshwater biology. World Health Organization

Biernacka I. (1963) Die Protozoenfauna in Dantziger Bucht. II. Die Charakteristik der Protozoen in Untersuchten Biotopen der Seekuste. Pol. Arch. Hydrobiol. 11: 53-75

Bock K. J. (1952) Über die marinen Arten der Gattung Thuricola (Ciliata, Peritricha). Kieler Meeresforsch. 8: 227-228

Bock K. J. (1963) Über das Auftreten einer Thuricola (Ciliata, Peritricha) in Belebtschlamm. Zool. Anz. 171: 91-96

Chen X., Pan H. B., Huang J. B., Warren A., Al-Farraj S.A., Gao S. (2016) New considerations on the phylogeny of cyrtophorian ciliates (Protozoa, Ciliophora): expanded sampling to understand their evolutionary relationships. Zool. Scr. 45: 334-348

Daday E. von. (1910) Untersuchungen über die Süsswasser-Mikrofauna Deutsch-Ost-Afrikas. Zoologica 22: 1-314

Dons C. (1922) Notes sur quelques Protozoaires marins. Vidensk. Meddel. Meddel. Dansk. Naturh. Foren. 73: 49-84 
Dons C. (1948) On some marine sedentary protozoans from Tristan da Cunha. Res. Norwegian Sci. Exped. Tristan da Cunha 19371938, 16: 1-16

Entz G. (1904) Einiges uber das variieren der infusorien. Mat. Naturwiss. Ber. Ungarn. 19:125-144.

Eperson S. (1980) Sur la stomatogenèse et les relations phylogenétiques du cilié pèritricha Thuricola folliculata (O. F. Müller, 1786). Protistologica 16: 549-564

Foissner W. (1988) A taxonomic and nomenclatural revision of Sladecek's list of ciliates (Protozoa: Ciliophora) as indicators of water quality. Hydrobiologia 166: 1-64

Foissner W., Berger H., Kohmann F. (1992) Taxonomische und ökologische Revision der Ciliaten des Saprobiensystems - Band II: Peritrichida, Heterotrichida, Odontostomtida. Informationsberichte des Bayer. Landesamtes Wasserwirtsch. 5/92: 1-502

Foissner W., Blake N., Klaus W. O. L. F., Breiner H. W., Stoeck T. (2010) Morphological and molecular characterization of some peritrichs (Ciliophora: Peritrichida) from tank bromeliads, including two new genera: Orborhabdostyla and Vorticellides. Acta Protozool. 48: 291-319

Fromentel E. de. (1874-1876) Études sur les microzoaires ou infusoires proprement dits omprenant de nouvelles recherches sur leur organization, leur classification et la description des espèces nouvelles ou peu connus. G. Masson, Paris

Gao F., Huang J. A., Zhao Y., Li L. F., Liu W. W., Miao M., Zhang Q. Q., Li J. M., Yi Z. Z., El-Serehy H. A., Warren A., Song W. B. (2017) Systematic studies on ciliates (Alveolata, Ciliophora): progress and achievements based on molecular information. Eur. J. Protistol. 61: 409-423

Gao F., Li J. M., Song W., Xu D., Warren A., Yi Z. Z., Gao S. (2016a) Multi-gene-based phylogenetic analysis of oligotrich ciliates with emphasis on two dominant groups: Cyrtostrombidiids and strombidiids (Protozoa, Ciliophora). Mol. Phylogenet. Evol. 105: 241-250

Gao F., Warren A., Zhang Q. Q., Gong J., Miao M., Sun P., Xu D., Huang J. A., Yi Z. Z., Song W. B. (2016b) The all-data-based evolutionary hypothesis of ciliated protists with a revised classification of the phylum Ciliophora (Eukaryota, Alveolata). Sci. Rep. 6: 24874

Gentekaki E., Kolisko M., Gong Y., Lynn D. (2017) Phylogenomics solves a long-standing evolutionary puzzle in the ciliate world: The subclass Peritrichia is monophyletic. Mol. Phylogenet. Evol. 106: 1-5

Gong X. J. (1989a) Descriptions of six new species of peritrich from Xinjiang, China. Acta Hydrobiol. Sin. 14: 396-403 (in Chinese with English summary)

Gong X. J. (1989b) Descriptions of three new species of peritrich from Qinghai province, China, Acta Hydrobiol. Sin. 14: 257261 (in Chinese with English summary)

Hall T. A. (1999) BioEdit: a user-friendly biological sequence alignment editor and analysis program for Windows 95/98/NT. Nucleic Acids Symp. Ser. 41: 95-98

Hammann I. (1952) Ökologische und biologische Untersuchungen an Süßwasserperitrichen. Arch. Hydrobiol. 47: 177-228

Huang J. B., Luo X. T., Bourland W. A., Gao F. Gao S. (2016) Multigene-based phylogeny of the ciliate families Amphisiellidae and Trachelostylidae (Protozoa: Ciliophora: Hypotrichia). Mol. Phylogenet. Evol. 101: 101-110

Jerome C. A., Simon E. M., Lynn D. H. (1996) Description of Tetrahymena empidokyrea $\mathrm{n}$. sp., a new species in the Tetrahymena pyriformis sibling species complex (Ciliophora, Oligohymeno- phorea), and an assessment of its phylogenetic position using small-subunit rRNA sequences. Can. J. Zool. 74: 1898-1906

Ji D., Kim J. H., Shahed S. U. A., Sun P., Li L. F., Shin M. K. (2015) Two new species of Zoothamnium (Ciliophora, Peritrichia) from Korea, with new observations of $Z$. parahentscheli Sun et al., 2009. J. Eukaryot. Microbiol. 62: 505-518

Jiang X. Z., Shen Y. F., Gong X. J. (1983) Aquatic invertebrates of the Tibetan Plateau. Science Press, Beijing

Kahl A. (1933) Ciliata libera et ectocommensalia. In: Grimpe, G., Wagler, E. (Eds.), Tierwelt Nord Ostsee 23 (Teil II, c3). 29-146

Kahl A. (1935) Urtiere oder Protozoa I: Wimpertiere oder Ciliata (Infusoria) 4 Peritricha und Chonotricha. Tierwelt Dtl. 30: 651886

Kellicott D. S. (1884) Observations on infusoria, with descriptions of new species. Proc. Amer. Soc. Microsc. 6: 110-125

Kent W. S. (1881-1882) A manual of the infusoria: including a description of all known flagellate, ciliate, and tentaculiferous protozoa British and foreign, and an account of the organization and affinities of the sponges. David Bogue, London (Vol. II 1881: 433-720; Vol. III 1882: Plates)

Kudo R. R. (1939) Protozoology, second edition. Charles C Thomas, Springfield, Illinois

Kumar S., Stecher G., Tamura K. (2016) MEGA7: Molecular evolutionary genetics analysis version 7.0 for bigger datasets. Mol. Biol. Evol. 33: 1870-1874

Küsters E. (1974) Ökologische und systematische Untersuchungen der Aufwuchsciliaten im Königshafen bei List/Sylt. Arch. Hydrobiol. (suppl.) 45: 121-211

Landan G., Graur D. (2008) Local reliability measures from sets of co-optimal multiple sequence alignments. Pac Symp. Biocomput. 13: 15-24

Li J. M., Liu W. W, Gao S., Warren A., Song W. B. (2013) Multigene-based analyses of the phylogenetic evolution of oligotrich ciliates, with consideration of the internal transcribed spacer 2 secondary structure of three systematically ambiguous genera. Eukaryot. Cell 12: 430-437

Liebmann H. (1962) Handbuch der Frischwasser- und Abwasserbiologie. Biologie des Trinkwassers, Badewassers, Fischwassers, Vorfluters und Abwassers. Band I (2nd ed.), 588

Liu W. W., Jiang J. M., Xu Y., Pan X. M., Qu Z. S., Luo X. T., Warren A., Ma H. G., Pan H. B. (2017) Great diversity in marine ciliates: fauna studies in China seas during the years 2011-2016. Eur. J. Protistol. 61: 424-438

Lu X., Huang J. A., Shao C., Al-Farraj S. A., Gao S. (2017) Morphology and morphogenesis of a novel saline soil hypotrichous ciliate, Gonostomum sinicum nov. spec. (Ciliophora, Hypotrichia, Gonostomatidae), including a report on the small subunit rDNA sequence. J. Eukaryot. Microbiol. 64: 632-646

Lynn D. H. (2008) The ciliated protozoa: characterization, classification, and guide to the literature, third edition. Springer, Dordrecht

Medlin L., Elwood H. J., Stickel S., Sogin M. L. (1988) The characterization of enzymatically amplified eukaryotes $16 \mathrm{~S}$-like ribosomal RNA coding regions. Gene 71: 491-500

Müller, O. F. (1786) Animalcula infusoria fluviatilia et marina. Havniae et Lipsize

Nusch E. A. (1970) Ökologische und systematische Untersuchungen der Peritricha (Protozoa, Ciliata) im Aufwuchs von Talsperren und Flusstauen mit verschiedenem Saprobitatsgrad (mit Modellversuchen). Arch. Hydrobiol. (suppl.) 37: 243-386

Nylander J. A. A. (2004) MrModeltest version 2. Evolutionary Biology Centre, Uppsala University, Uppsala 
Pan H. B., Jiang J. M., Fan X., Al-Farraj S. A., Gao S. (2017) Phylogeny and taxonomy of five poorly known species of cyrtophorian ciliates (Protozoa: Ciliophora: Phyllopharyngea) from China Seas. Zool. J. Linn. Soc. 180: 475-492

Pan X. M., Bonrland W., Song W. B. (2013) Protargol synthesis: an in-house protocol. J. Eukaryot. Microbiol. 60: 609-614

Penard E. (1914) Les cothurnidés muscicoles. Mém. Soc. Phys. Hist. Nat. Genève 38: 19-68

Penard E. (1922) Études sur les Infusoires d'eau douce. Georg \& Cie, Genève 1-331

Peng X., Shi X., Warren A. (2007) Establishment of a new peritrich ciliate genus, Pseudepistylis n. gen. (Ciliophora: Peritrichia: Epistylididae), with a description of a new freshwater species, Pseudepistylis songi n. sp. from Wenzhou, China. Zootaxa 1524: $35-45$

Qu Z. S., Pan H. B., Al-Rasheid K. A. S., Hu X., Gao S. (2015) Morphological and phylogenetic studies on three members of the genus Pseudochilodonopsis (Ciliophora, Cyrtophoria) isolated from brackish waters in China, including a novel species, Pseudochilodonopsis quadrivacuolata sp. nov. Int. J. Syst. Evol. Microbiol. 65: 4323-4334

Ronquist F., Teslenko M., Van Der Mark P., Ayres D. L., Darling A., Höhna S., Larger B., Liu L., Suchard M. A., Hurlsenbeck J. P. (2012) MrBayes 3.2: efficient Bayesian phylogenetic inference and model choice across a large model space. Syst. Biol. 61: 539-542

Sela I., Ashkenazy H., Katoh K., Pupko T. (2015) GUIDANCE2: accurate detection of unreliable alignment regions accounting for the uncertainty of multiple parameters. Nucleic Acids Res. 43: W7-W14

Shen Y. F., Gu M. R. (2016) Fauna Sinica: Invertebrata vol. 45 Ciliophora Oligohymenophorea Peritrichida. Science Press, Beijing

Shen Z., Ji D., Yi Z. Z., Al-Rasheid K. A. S., Lin X. (2017) Morphology and phylogenetic placement of three new Zoothamnium species (Ciliophora: Peritrichia) from coastal waters of southern China. J. Eukaryot. Microbiol. 64: 266-277

Sommer G. (1951) Die peritrichen ciliaten des Grossen Plöner Sees. Arch. Hydrobiol. 44: 349-440

Sun P, Al-Farraj S. A., Warren A., Ma H. G. (2017) Morphology of four new solitary sessile peritrichs (Ciliophora, Peritrichia) from the Yellow Sea, China, with description on an unidentified species of Paravorticella. Eur. J. Protistol. 57: 73-84

Sun P., Clamp J. C., Xu D., Huang B., Shin M. H. (2016) An integrative approach to phylogeny reveals patterns of environmental distribution and novel evolutionary relationships in a major group of ciliates. Sci. Rep. 6: 21695

Sun P., Clamp J. C., Xu D., Kusuoka Y., Miao W. (2012) Vorticella Linnaeus, 1767 (Ciliophora, Oligohymenophora, Peritrichia) is a grade not a clade: Redefinition of Vorticella and the families Vorticellidae and Astylozoidae using molecular characters derived from the gene coding for small subunit ribosomal RNA. Protist 163: 129-142

Sun P., Ji D., Warren A., Song W. B. (2009) Solitary sessilid peritrichs. In: Free-living ciliates in the Bohai and Yellow Seas, China, (Eds. W.B Song, A. Warren, X. Hu). Science Press, Beijing, 251-254
Stamatakis A. (2014) RAxML version 8: a tool for phylogenetic analysis and post-analysis of large phylogenies. Bioinformatics 30: 1312-1313

Stiller J. (1971) Szájkoszorús csillósok. - Peritricha. Fauna Hung. 105: $1-245$ (in Hungarian)

Stokes A. C. (1882) A new Thuricola. Amer. Month. Microsc. J. 3: $182-183$

Stokes A. C. (1887) Notices of new fresh-water infusoria. Proc. Am. Phil. Soc. 24: 244-255

Stokes A. C. (1888a) A generic synopsis of the sedentary freshwater Peritricha. An elementary chapter for beginners. Amer. Month Microsc. J. 9: 59-64

Stokes A. C. (1888b) A preliminary contribution toward a history of the fresh-water infusoria of the United States. J. Trenton Nat. Hist. Soc. 1: 71-344

Trueba F. J. (1978) A taxonomic revision of the peritrich ciliate genus Pyxicola. Beaufortia 27: 219-243

Trueba, F. J. (1980) A taxonomic revision of the peritrich ciliate genera Thuricola and Pseudothuricola. Beaufortia 30: 125-138

Wang P., Wang Y. R., Wang C. D., Zhang T. T., Al-Farraj S. A., Gao F. (2017) Further consideration on the phylogeny of the Ciliophora: Analyses using both mitochondrial and nuclear data with focus on the extremely confused class Phyllopharyngea. Mol. Phylogenet. Evol. 112: 96-106

Warren A. (1982) A taxonomic revision of the genus Platycola (Ciliophora: Peritrichida). Bull. Br. Mus. nat. Hist. Zool. 43: 95-108

Warren A. (1991) A revision of Cothurnia (Ciliophora: Peritrichida). Bull. Br. Mus. nat. Hist. Zool. 57: 17-59

Wilbert N. (1975) Eine verbesserte Technik der Protargolimprägnation für Ciliaten. Mikrokosmos 64: 171-179

Wright T. S. (1858) Description of new protozoa. Edingburgh New Philos. J. 7: 276-281

Xu Z. K. (1990) Notes on two new species of genus Thuricola from Tianjin. Acta Zootaxon. Sin. 15: 6-9 (in Chinese with English summary)

Yan Y., Xu Y., Al-Farraj S. A., Al-Rasheid K. A. S., Song W. B. (2016a) Morphology and phylogeny of three trachelocercids (Protozoa, Ciliophora, Karyorelictea), with description of two new species and insight to the evolution of the family Trachelocercidae. Zool. J. Linn. Soc. 177: 306-319

Yan Y., Fan Y., Chen X. R., Li L. F., Warren A., Al-Farraj S. A., Song W. B. (2016b) Taxonomy and phylogeny of three heterotrich ciliates (Protozoa, Ciliophora), with description of a new Blepharisma species. Zool. J. Linn. Soc. 177: 320-334

Zhuang Y., Clamp J. C., Yi Z. Z., Ji D. (2016) A new peritrich ciliate from a hapersaline habitat in northern China. Zootaxa 4169: 179-186

Zhuang Y., Clamp J. C., Yi Z. Z., Ji D. (2018) Phylogeny of the families Zoothamniidae and Epistylididae (Protozoa: Ciliophora: Peritrichia) based on analyses of three rRNA-coding regions. Mol. Phylogenet. Evol. 118: 99-107

Received on $9^{\text {th }}$ March, 2018; revised on $24^{\text {th }}$ April, 2018; accepted on $1^{\text {st }}$ May, 2018 